ROCIO ANAHI ZARAGOZA DOUGLAS

\title{
RESPOSTA INFLAMATÓRIA IMEDIATA DE CINCO CIMENTOS ENDODÔNTICOS DIANTE DO TESTE EDEMOGÊNICO EM SUBCUTÂNEO DE RATOS
}


ROCIO ANAHI ZARAGOZA DOUGLAS

Resposta inflamatória imediata de cinco cimentos endodônticos diante do teste edemogênico em subcutâneo de ratos

Dissertação apresentada à Faculdade de Odontologia da Universidade de São Paulo, para obter do título de Mestre, pelo Programa de Pós-Graduação em Ciências Odontológicas

Área de Concentração: Endodontia

Orientador: Prof. Dr. Marcelo dos Santos

São Paulo 


\section{FOLHA DE APROVAÇÃO}

Zaragoza RAD. Resposta inflamatória imediata de cinco cimentos endodônticos diante do teste edemogênico em subcutâneo de ratos [Dissertação de Mestrado]. São Paulo: Faculdade de Odontologia da USP; 2008.

São Paulo, 01/04/2008

\section{BANCA EXAMINADORA}

1) $\operatorname{Prof}(a) . \operatorname{Dr}(\mathrm{a}) .:$

Titulação:

Julgamento:

Assinatura:

2) $\operatorname{Prof}(\mathrm{a}) \cdot \operatorname{Dr}(\mathrm{a})$ :

Titulação:

Julgamento:

Assinatura:

3) $\operatorname{Prof}(a) \cdot \operatorname{Dr}(a)$ :

Titulação:

Julgamento:

Assinatura: 
Dedicatorias 
Àquele que me carregava em seus braços quando eu já duvidava...

"senhor, concedei-me serenidade para aceitar as coisas que nä॰ poss๑ modificar, coragem para modificar aquelas que posso e sabedoria para distinguir umas das outras"

O amor de Deus os uniu, o amor entre vocês me trouxe ao mundo, o amor de vocês me fez chegar até aqui. $E$ hoje, adulta, enxergo que sem o único e verdadeiro amor, ninguém faria por mim tudo que vocês fizeram.

Meu papai, minha mamãe.o• Esta dissertagäo é sem sombra de dúvidaıo nossa. 
Christian Andrés Zaragoza Douglas

Meu irmão querido, comemoramos juntos minha aprovação no vestibular. E já no primeiro ano do meu curso de graduação, fostes embora e te tornastes meu guia junto do Pai. Tu és meu anjo e a ti dedico mais esta conquista.

saudades sempre do seu sorriso tímido.o.

Obrigada pela sua luz!

"Sua ausência é a maior presenģa em meu caminho" 


\title{
Alvaro Rodrigo Zarageza Douglas Iuan Ramiro Zaragoza Douglas
}

Á, e lvanzinho... Cada um de vocês tem sua maneira de cuidar de mim, não importa quando, onde, nem como... Importa sabermos que o amor entre irmãos, assim como entre pais e filhos é incondicional. Aprendemos com nossos pais e certamente levaremos para nossas vidas.

Dedico a vocês também esta vitória!

\section{Elaine Gristina Denadai Zarageza Graziela Forgati Muzatio}

Lã e Gra...

Vocês duas fazem parte daquilo que chamo a "família de casa"... Como não dedicar a vocês, que me apoiaram em todos os momentos da confecção desta dissertação? Amo vocês verdadeiramente como minhas irmãs...

Obrigada por compreenderem minhas ausências!

\author{
César Augusto Denadai Zaragoza \\ Maria Gabriela Denadai Zaragoza
}

Meus sobrinhos...minha afilhada...

Meus "terapeutas"... Pelas vezes que os deixei sem um "esconde-esconde", pelo aniversário que não estive presente, por dividi-los muitas vezes com o computador... Neste momento vocês ainda não são capazes de compreender, mas fica aqui o registro... Em algum momento certamente poderei retribuir a paciência, o amor e os momentos de alegria que só vocês são capazes de me proporcionar...

A Tia Rô os amará eternamente! 


\section{AGRADECIMENTOS}




\section{Ao Prof. Eduardo Akisue}

Meu "mini-orientador"...

Formamos uma verdadeira parceria, tentamos fazer acontecer algo de bom e sério dentro daquilo que nos propusemos.

Com sua paixão pela pesquisa e a minha pelo ensino, este é o primeiro fruto dentro de tantas sementes que plantamos ao longo dos anos...

Jamais poderei agradecer a sua companhia madrugadas afora nos laboratórios, a superação do cansaço para encontrarmos mais uma resposta, as calorias ingeridas ao final de cada etapa, os risos, os choros e sua paciência com minhas inquietações... Eu me orgulho de poder trabalhar com você. Minha jornada termina aqui, mas de sorte ainda temos a sua para continuarmos a caminhada juntos. E você sabe bem o que eu desejo e espero para seu futuro acadêmico... 


\section{Ao meu orientador, Prof. Dr. Marcelo dos Santos}

Fostes aquele que me acolheu aos recém completos 21 anos no Curso de Especialização. Desde aquele dia são nove anos de convivência entre encontros e desencontros. Muita confiança e muitos desafios foram por você depositados em mim. Serei eternamente grata por ter chegado pelas suas mãos à FOUSP, ao Curso de Pós-Graduação, à Associação Americana de Endodontia e até a autoria de um capítulo de liuro... Obrigada, de coragäo, por tudo que fizestes por mim até aqui!

A Profa. Dra. Primavera Borelli

Há quase dois anos fui recebida no laboratório para os primeiros pilotos. Em um mês você me confiou as chaves, as entradas noturnas e aos fins de semana. Nunca poupou tempo para me receber, nem delicadas palauras para mostrar quando me faltava mais. Ingressei no Curso de Mestrado querendo tornar-me professora e ao seu lado me apaixonei pela pesquisa. Hoje me sinto orgulhosa por ter a honra de trabalhar com uma verdadeira

PESQUISADORA-EDUCADORA!

Obrigada!

Ao Prof. Dr. Antonio Carlos Bombana

Eu voltei a Santo André pelo seu nome, indicado pelo Prof. Bebeto. Buscava um Curso de Especialização. Jamais imaginei ter a honra de tornar-me mestre com a sua assinatura. Mas hoje nada disso importa mais.... Desde aquela idolatria juvenil, conheci um Bombana por quem minha admiração hoje transcende qualquer título.

Parceirosoos sempre!

\section{A Profa. Dra. Patrieia Helena Pereira Ferrari}

Sua presença em minha vida mudou meu rumo acadêmico. Eu jamais estaria aqui se não tivéssemos criado laços, trocado experiências. Muito mais que admiração pela Profa.

Patrícia, sou eternamente grata pelos seus ensinamentos de vida. Se hoje defendo esta dissertação, grande parte desta conquista deve-se a amizade que um dia construímos. sinceramente obrigada! 
De professor sério durante os créditos, tornamo-nos amigos. De amigos, companheiros de trabalho porque você confiou em mim e me abriu portas...

Conheci um profissional autêntico, cheio de hombridade e hoje me sinto feliz em poder chamá-lo de... Meu amigo.

Obrigada por estar ao meu lado nos momentos em que mais precisei!

A॰ Prof. Dr. Giulio Gavini

Esta dissertação nasceu a partir de uma atividade de crédito que você ministrava. Eu cheguei ao laboratório levada por um orientado seu. Tive a honra de tê-lo como membro na minha Banca de Qualificação (ainda que por obra do acaso) e por fim, estamos lado a lado trabalhando no Curso de Graduação. Espero poder sempre fazer jus à confiança em mim depositada.

Minha admiragä̊ por você cresce a cada dia!

Ao Prof. Dro Haroldo Arid soares e a Profa. Nelsa Akemi Ishimoto Meus grandes mestres do Curso de Graduação... À vocês, basta simplesmente dizer... Vocês foram meus melhores exemplos do que é SER EDUCADOR lá em Bragança Paulista. Fico feliz e orgulhosa em poder dizer isso. suas presengas em minha história sc̆॰ inesqueciveis!

\section{Aos demais professores da Discliplina de Endodontia da FOUSP} Profso Antoniazzi, Aun, Abilio, Lage-Marques, Machado e Igor

Ainda que não tenhamos nos proporcionado mais contato de trabalho do que foi possivel nos tempos de créditos, entendo que uma Disciplina é formada por muitos membros e sei a importância de cada um de vocês nesta equipe.

Obrigada por aereditarem em mim!

A secretária do Departamento Ana Maria de souza

Pela sua paciência, pela dedicação, pela atenção, pelas broncas nas horas certas, pelo seu sorriso e carinho...

Obrigada por tudo! 


\section{Aos colegas do Laboratório de Hematologia da Faculdade de Ciêneias Farmacêuticas da USP \\ Chico, Amanda, Mariana, Karina, Marcelo e Ricardo}

Cada um com seu experimento, cada um no seu momento, mas todos, sem exceções, dispostos a parar tudo para ensinar ou ajudar. Trocamos experiências únicas.

Muito obrigada por tudo!

Aos meus colegas de Pós-Graduagão

André, Akisue, Angela, Cabrales, Cacio, Janet, Marina, Patricia e Soraia

As lembranças de nosso tempo de créditos estão registradas em fotografias, mas 0 sentimento que ficou em mim foram saudades... dos seminários, das discussões, da Bioética, da Bioestatística, da Metodologia... Enfim, hoje ingresso num novo curso e espero ansiosamente encontrar uma turma como vocês.

Valeu!

A minha amiga Profa. Patricia Guerreiro Monteiro

Você me permitiu acreditar que é possível não concorrer, e sim formar equipe. Ultrapassamos as barreiras profissionais e nos tornamos amigas. Para quaisquer momentos ou "eventos"...

Obrigada por estar a๑ meu lado!

As minhas amigas Carla Gury e Eliane Ribeiro Pelas alegrias divididas, pelos sonhos somados, pelos desacertos subtraídos. Por tudo o que vivemos. Nunca poderei estar distante de vocês sejam quais forem nossos rumos.

Meu carinho e minha amizade sempre para vocês!

Aos meus amigos da FUNDECTO Margarete, Claudia, Karina, Lieni, Angélica, Isabel, Yolanda, Milena, Alexandre e Marcelo

Durante todo o tempo de pós-graduação e principalmente hoje, vocês são minha equipe de ensino. A capacidade de interagir, de dividir trabalho sem sobrecarregar, de não fazer diferenças, de compreender quando necessário... Vivenciar a prática do ensino com vocês é ímpar para o meu crescimento. 
A APCD-Santo André

À entidade, aos amigos funcionários, aos amigos da Diretoria. Ao lado de vocês minha história de cirurgiā-dentista começou. Vocês fazem parte do meu caminho e da minha

história. Formalizo meus agradecimentos citando pessoas que me apoiaram sempre:

Joana, Lucilene, Heloísa e Gabellini.

Levem meus agradecimentos a todos que trabalharam comigo desde 1998!

Aos amigos dos Cursos de Endodontia da APCD-santo André

Marcelo, Patrícia, Evandro, Luigina, Cris, Jussara, Patrícia Mo, Eliane e Carla

Ao lado de vocês comecei a aprender a arte de ensinar e com vocês vivenciei experiências que jamais poderei olvidar. Foram anos de convivência, minha primeira escola, minha primeira equipe...

Obrigada!

\begin{abstract}
A todos os meus colegas de consultório
Na Clínica Greggio, na CEROS e na LV Odontologia Como não agradecer a paciência pelas ausências, a compreensão com minha falta de paciência e a confiança no meu trabalho.

É muito bom trabalhar com vocês!
\end{abstract}

\begin{abstract}
Aos amigos Lieni e lvo
Somos conhecidos de longa data, mas no último ano fui "adotada" por vocês. Tornaram-se grandes companheiros para quaisquer situaçōes... Sem questionar ou condicionar minha vida e minhas escolhas estiveram ao meu lado e cuidaram de mim... Tornei-me uma "vela" oficial entre vocês e sempre senti carinho e companheirismo nas mais duras situações. Para finalizar, estiveram literalmente ao meu lado nos momentos finais desta redação...

Para retribuir apenas posso dizero.o CONTEM COMICO!
\end{abstract}

Ao amigo Rodrige da Costa Aguiar

Nossa amizade é uma verdadeira relação de irmãos.

Sua presença em minha vida não tem preço.

Obrigada por cada palaura de apoio e carinho durante todos esses anos. Conte comigo para sempre. Nossa amizade é eterna! 


\section{Ló - Profa. Dra. Angela Scarparo Caldo-Teixeira}

Sem sombra de dúvidas você é minha maior torcida. Moramos juntas apenas $1 / 3$ do tempo que já dura nossa amizade e sua presença em minha vida pessoal e acadêmica ao longo desse tempo é ímpar e imensurável. Mesmo com os quilômetros que hoje nos separam, você é um das pessoas que mais fizeram parte da confecção deste trabalho, as trocas de dicas pelo MSN aos fins de semana e feriados jamais serão esquecidos. Obrigada!

Eternamente lado a lado!

Adri, Selminha e Alexandra

Anos de amizade, apoio e conviver diário. Vocês dividiram comigo as sementes, as folhas, os frutos, os espinhos e as flores deste trabalho. Eu não existo sem vocês, vocês são minhas irmãs de coração e àquelas que mais me conhecem e compreendem. Estarei sempre ao lado de vocês. Nossa amizade não tem limites.

Amø muite vocês!

\footnotetext{
Minhas queridas companheiras de República

Eliane, Flavinha, Ló, Marina, Nanci, Paulinha, Selminha, Tamie, Tati e Vivi Vocês dividiram comigo este sonho e certamente estão hoje felizes por mim. Minhas amigas Toc-Tocs: 15 anos, 20 anos ... Passem quantos anos passarem... Nossos adoráveis encontros durarä̊ para sempre!
}

"A única maneira de ter amigos é ser amigo". (R. Waldo) 
Mesmo quando tudo pede

Um pouco mais de calma

Até quando o corpo pede

Um pouco mais de alma

$A$ vida não pára...

Enquanto todo mundo

Espera a cura do mal

E a loucura finge

Que isso tudo é normal

Eu finjo ter paciência...

O mundo vai girando

Cada vez mais veloz

A gente espera do mundo

E o mundo espera de nós

Um pouco mais de paciência...

A vide é täo raraoo

(Lenine/Dudu Falcão)

"Por isso existem momentos inescueciveis, coiscas inexplicáveis e pessoas incomparáveis"

(Fernando Pessoa) 
Zaragoza RAD. Resposta inflamatória imediata de cinco cimentos endodônticos diante do teste edemogênico em subcutâneo de ratos [Dissertação de Mestrado]. São Paulo: Faculdade de Odontologia da USP; 2008.

\section{RESUMO}

Este estudo teve como objetivo avaliar, in vivo, por um período de $24 \mathrm{~h}$, a resposta tecidual inflamatória subcutânea após a utilização de cimentos endodônticos. Realizouse a seleção de 75 ratos, machos, da linhagem Wistar, de aproximadamente 90 dias (de vida) e com cerca de $350 \mathrm{~g}$ (de peso), que foram aleatoriamente distribuídos em 5 grupos ( $n=20$ ), como se segue: G1 - ActiV GP ${ }^{\mathrm{TM}}, \mathrm{G} 2$ - Biosealer, G3 - RealSeal ${ }^{\oplus}, \mathrm{G} 4$

- RoekoSeal ${ }^{\circledast}$ e G5 - AH Plus ${ }^{\circledast}$. A resposta inflamatória foi observada pelo teste edemogênico, nos tempos 6, 12 e 24 horas. Como protocolo de aplicação da metodologia, os animais depois de anestesiados, receberam uma injeção do corante vital Azul de Evans na veia lateral caudal. Em seguida, foram tricotomizados em seu dorso e, doses iguais dos materiais estudados foram inseridas subcutaneamente. Ao final de cada período de tempo, realizou-se a remoção da pele dorsal em fragmentos de $15 \mathrm{~mm}$ de diâmetro. Os fragmentos foram imersos em solução de formamida P.A., armazenados em estufa a $37^{\circ} \mathrm{C}$, por 48 horas. Nesse momento, os índices de absorbância do corante extraído pelo solvente foram quantificados por meio de espectrofotometria, os resultados convertidos em microgramas $(\mu \mathrm{g})$ e a concentração de cada substância no infiltrado inflamatório obtida. Os dados obtidos foram submetidos a ANOVA e teste de Tukey $(p<0,05)$. E, de acordo com os resultados obtidos, observou-se que houve diferenças estatisticamente significativas para os fatores em estudo material $(p<0,0001)$ e tempo $(p<0,0001)$, entretanto não houve interação material*tempo $(p=0,128)$. Sendo assim, nas primeiras $6 \mathrm{~h}$, a ordem 
decrescente de irritabilidade dos materiais analisados foi: G3 $\approx \mathrm{G} 5>\mathrm{G} 1>\mathrm{G} 2>\mathrm{G} 4$. Entretanto, os materiais desempenharam-se de forma semelhante, tanto no tempo de $12 \mathrm{~h}$ quanto no de $24 \mathrm{~h}$, como se segue: $\mathrm{G} 1 \approx \mathrm{G} 3 \approx \mathrm{G} 5>\mathrm{G} 2 \approx \mathrm{G} 4$. Desta forma, pôde-se concluir que: 1 - o cimento RoekoSeal demonstrou o menor grau de irritabilidade no tempo experimental de 6 horas; 2 - Os cimentos RealSeal e AH Plus apresentaram resposta inflamatória mais intensa no período experimental de 6 horas e 3 - o índice de irritabilidade nas primeiras 6 horas é significativamente superior quando comparado ao período de $24 \mathrm{~h}$, independente do material testado.

Palavras-Chave: Obturação do Canal Radicular; Materiais Biocompatíveis; Azul Evans; Resposta Inflamatória 
Zaragoza RAD. Immediate inflammatory response of five endodontic sealers using the edemogenic test in subcutaneous of mice [Dissertação de Mestrado]. São Paulo: Faculdade de Odontologia da USP; 2008.

\section{ABSTRACT}

The aim of this study was evaluate in vivo the earliest 24 hours tissue inflammatory response to five endodontic sealers. In order to this, 75 male rats Wistar with 90 days of age and approximately $350 \mathrm{~g}$ of weight were divided in 5 experimental groups $(n=20):$ G1 - ActiV GP'м, G2 - Biosealer, G3 - RealSeal ${ }^{\circledR}, G 4$ - RoekoSeal ${ }^{\circledR}$ e G5 AH Plus ${ }^{\circledast}$. The inflammatory response was evaluated using the edemogenic test in the experimental periods of 06,12 and 24 hours. Anesthetized mice received an Evan's blue dye injection in the lateral caudal vein and were tricotomized in the dorsum where equal amounts of each sealer were subcutaneously inoculated. After experimental period, the mice were sacrified, the dorsal skin was excised and pieces with $15 \mathrm{~mm}$ of diameter around each inoculated sealer were removed. Each tissue piece was reduced to fragments, immersed in formamide solution and stored at $37^{\circ} \mathrm{C}$ during 48 hours. At this moment, the absorbance index of the dye extracted by the solvent was quantified using light absorption spectrometry, the results were converted to micrograms $(\mu \mathrm{g})$ and their concentration in the inflammatory infiltrated was obtained. The data was submitted to statistical analysis using the ANOVA followed by the Tukey test $(p<0.05)$ and the results showed statistical significant difference for analyzed factors, the material and the time $(p<0.001)$; without interaction between both $(p=0.128)$. Thus, in decrescent order inflammatory response, the groups were scaled: $G 3 \approx G 5>G 1>G 2>G 4$ for 6 hours, 
and $\mathrm{G} 1 \approx \mathrm{G} 3 \approx \mathrm{G} 5>\mathrm{G} 2 \approx \mathrm{G} 4$ for 12 hours and 24 hours. Our findings indicated that: 1 - The RoekoSeal presented the minor inflammatory response value in the 6 hours experimental period; 2 - The RealSeal and $\mathrm{AH}$ Plus sealers showed intense inflammatory response in the experimental period of 6 hours; 3 - The inflammatory values at 6 hours were significantly higher compared with results in the period of 24 hours independently of the tested material.

Key-words: Root canal filling, biocompatibility, inflammatory response, edemogenic test 


\section{SUMÁRIO}

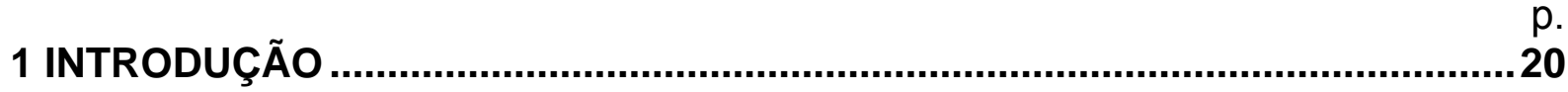

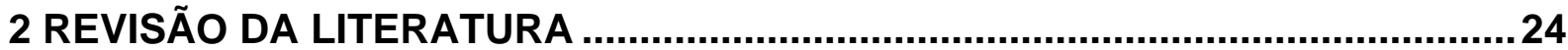

2.1 Resposta tecidual imediata - Processo Inflamatório....................................25

2.2 Azul de Evans - Teste Edemogênico ................................................... 29

2.3 Biocompatibilidade - Outros estudos ................................................... 42

3. PROPOSIÇÃO .......................................................................................... 51

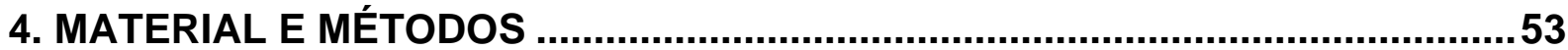

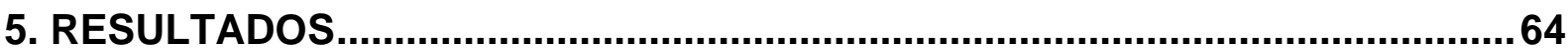

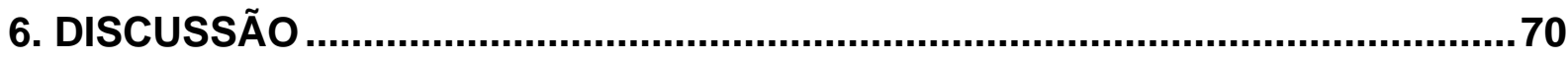

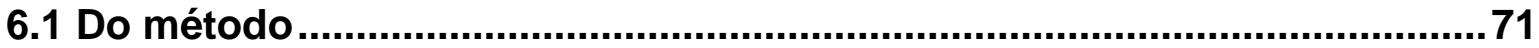

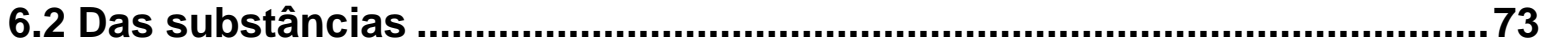

6.3 Dos resultados......................................................................................... 77

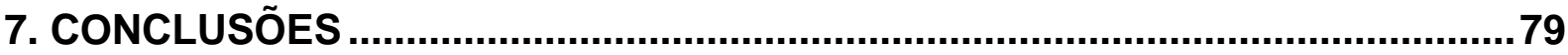

REFERÊNCIAS....................................................................................... 81

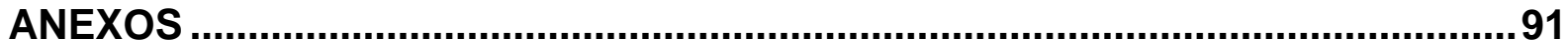




\section{INTRODUÇAO}




\section{INTRODUÇÃO}

A compatibilidade biológica é requisito primordial para os materiais obturadores, independentemente de sua composição. Substâncias demasiadamente irritantes para os tecidos periapicais podem causar intensa inflamação, e conseqüente necrose tecidual nesta área, reações que podem comprometer desde o pós-operatório do paciente até mesmo o sucesso da terapia endodôntica (BUNCZAK-REEH; HARGREAVES, 1998; COHEN et al., 2000).

Com o passar dos anos, novos cimentos obturadores vêm sendo apresentados como alternativas a aqueles empregados durante anos na terapia endodôntica, que têm em sua composição base como óxido de zinco e eugenol ou hidróxido de cálcio e ainda hoje são utilizados em larga escala. Esses novos cimentos apresentam-se em bases como resina epóxica, resinas plásticas, silicone, ionômero de vidro e ainda fitoterápicos.

Dessa maneira, foram apresentados nos últimos dez anos mais precisamente, substâncias tais como o cimento AH Plus, à base de resina epóxica, o RealSeal, à base de resina de metacrilatos, o RoekoSeal, à base de silicone, o cimento ActiV GP, com base de ionômero de vidro e também o Biosealer, que tem como base um fitoterápico amazônico.

Nos dias de hoje, apesar dos entraves quando se fala em pesquisas de biocompatibilidade no que tange a bioética, as metodologias científicas, utilizadas 
em estudos de citotoxicidade, têm demonstrado grande aceitabilidade e sucesso em sua aplicabilidade (GEHLEN, 2004; TRUJILLO JUNIOR, 2003).

O que se espera dos estudos in vivo, é que, ao permitir o contato do material a ser testado com um tecido semelhante aquele encontrado na região periapical, observe-se resposta inflamatória compatível com a esperada no processo reparacional (BRUNINI, 2001).

Levando-se em conta que a fase inicial da inflamação caracteriza-se por vasodilatação, aumento de permeabilidade e transmigração celular, na qual se observa a passagem de albumina plasmática do interior dos vasos para a matriz extracelular, é possível afirmar que a inflamação descontrolada é extremamente indesejável (GARCIA-LEME; SHAPOVAL, 1975; LEWIS, 1986; PEREIRA E BOGLIOLO, 1998).

A resposta inflamatória imediata, tomando-se como base as primeiras quarenta e oito horas após a injeção do agente flogogéno, pode ser analisada por um teste chamado edemogênico, que se caracteriza pelo emprego de uma substância corante, não tóxica, que tem efeito sistêmico edematogênico ao se ligar à albumina plasmática (RUTBERG; SPANGBERG; SPANGBERG, 1977).

Os primeiros estudos acerca de atividade edematogênica datam da década de 70 , quando pesquisadores buscavam um corante vital e o solvente ideal para sua extração e ainda o comprimento de onda adequado para sua leitura sob espectrofotometria.

O Azul de Evans, além de apresentar as características supracitadas, é também um fluoróforo, ou seja, apresenta a propriedade da fluorescência, o que permite mensurar, por meio de espectrofotometria, a sua presença em tecidos 
normais e irritados, que expressa através de um índice de absorbância, o extravasamento da albumina plasmática nessas áreas (CASTER; SIMON; ARMSTRONG, 1955; CLAUSEN; LIFSON, 1956).

Administrado intravenosamente, o corante, por meio da circulação busca as regiões nas quais ocorreu extravasamento celular, quanto mais líquido no interstício, mais plasma e mais inflamação.

O teste edemogênico tem sido utilizado com freqüência para avaliar a intensidade da reação inflamatória aguda, mensurando, por espectrofotometria, a densidade óptica de uma solução com corante extraído de um fragmento de tecido inflamado (BIANCONCINI, 2001; BORDÓN DE COBALÁN, 1994; GEHLEN, 2004).

No tempo experimental pré-determinado, a área que recebeu o material em teste é removida da solução solvente, e posteriormente observada sob espectrofotometria.

Com base nestas informações, podem-se concluir claros motivos para estudos acerca de biocompatibilidade destes novos materiais que vêm sendo inseridos como alternativas para a obturação endodôntica. 


\section{REUISAO DA LTERATURA}




\section{REVISÃO DA LITERATURA}

\subsection{Resposta Tecidual Imediata - Processo Inflamatório}

Conforme Robins, Cotran e Kuman (1984), inflamação é um processo defensivo local à agressão de agentes lesivos, caracterizada por fenômenos irritativos, vasculares, exsudativos, degenerativos e reparativos, acompanhados ou não de reparação geral do organismo. Sua finalidade é localizar o agente agressor, diluir, neutralizar, destruir, remover e reparar a área agredida.

Conhecendo os sinais característicos do processo inflamatório, Wilhelm (1982) afirmou que o calor e o rubor são resultados do aumento da microcirculação em torno da área lesada e que proteínas, células do plasma e líquido extravasado dos vasos sangüíneos ao tecido extravascular identificam o edema.

Cotran, Kunar e Robbins (1994), descrevem processo inflamatório como a reação do tecido vivo vascularizado a uma agressão local que ocupa um lugar vastamente estudado na medicina pela sua freqüência e importância na origem de grande parte das enfermidades que acometem o ser humano e os animais, conforme afirmaram também Correa, Arias-Stella e Tamoyo (1970).

Perez-Tamayo (1986) escreveu que independente de sua causa, o processo inflamatório se caracteriza por uma série de reações de células e tecidos a uma agressão, seguindo um modelo básico e estereotipado que se repete em muitas espécies diferentes. Entretanto a complexidade das alterações bioquímicas, 
morfológicas e funcionais que têm lugar durante o processo inflamatório, revela um interessante exemplo de homeostase.

Já segundo Rocha e Silva e Garcia-Leme (1972), o processo inflamatório pode também representar uma agressão aos tecidos e seu controle é desejável em muitas situações, como nas pneumonias, artrites, meningites, dentre outras. Dada a complexidade da reação, o processo inflamatório é ainda tema de numerosas pesquisas no meio científico. Essa complexidade se dá pela interação simultânea no local inflamado de vários componentes orgânicos, locais e sistêmicos, tais como microcirculação sangüínea e linfática, células e fibras do tecido conjuntivo, sistema endócrino e sistema nervoso.

Guyton (1976) explicou que em condições fisiológicas, não há passagem de proteínas plasmáticas dos capilares ao espaço intersticial. No entanto, na inflamação ocorre esta passagem, estimando-se como sendo de cinco a sete vezes maior do que num vaso normal. Além disso, a inflamação aguda e a injúria tissular causam alterações no fluxo sangüíneo, no calibre dos vasos, na permeabilidade vascular e na exsudação leucocitária. Por fim, o exsudato produzido quando existe alteração da permeabilidade vascular contém mais proteínas plasmáticas do que em situação normal.

Segundo Fantone, Peter e Ward (1990), a inflamação é uma reação da microcirculação caracterizada por um movimento de líquidos e leucócitos do sangue para os tecidos extra vasculares.

No passado, Konjetzny (1928) afirmara ser difícil definir a existência de um processo inflamatório se o componente da agressão fosse de baixa intensidade. Afirmou assim, que a inflamação transiciona-se com o aspecto normal e fisiológico, 
tornando-se impossível, pela histopatologia, dizer se o quadro observado está dentro da normalidade ou se é patológico.

Hoje, sabe-se que quando um tecido é danificado ou lesado, ocorre uma reação local que é referida como resposta inflamatória (LEWIS, 1986). À medida que as primeiras teorias científicas da inflamação surgiram, os pesquisadores acreditavam que as reações inflamatórias ocorriam independentemente, por exemplo, Cohnheim ${ }^{1}$ (1882, apud LEWIS, 1986), sugeria que a reação dos vasos sangüíneos era a resposta inicial ao estímulo inflamatório, ao passo que Metchnikoff $^{2}$ (1893, apud LEWIS, 1986), acreditava que os responsáveis pela resposta inicial ao processo inflamatório eram os leucócitos e fagócitos.

Cotran (1996), com o grande avanço das pesquisas, definiu que tanto a reação dos vasos quanto o deslocamento de leucócitos e fagócitos para a região inflamada, estão inter-relacionados na resposta inicial à inflamação.

O processo inflamatório pode representar a reação do tecido vivo vascularizado a uma agressão local de qualquer natureza, estando intimamente relacionado ao processo de reparo (LEWIS, 1986; TORABINEJAD; EBY; NAIDORF, 1985).

Cantazaro-Guimarães (1982) e Guyton e Hall (1998) afirmaram que imediatamente após a agressão inicial, cerca de dez a quinze minutos depois, a histamina e outros mediadores químicos atuam basicamente em veias pequenas e médias e não afetam capilares. A partir daí, dependendo da agressividade do agente

1 Cohnheim I. Lectures on general pathology. London: The new Sydenham Society; 1882. 
flogógeno, pode haver lesão também de células endoteliais, já afetando todos os níveis da microcirculação. O aumento da permeabilidade vascular e conseqüente extravasamento serão proporcionais a essa agressão.

Souza, Cunha e Ferreira (1994) reafirmaram que uma das características do processo inflamatório de acordo com nas formas superiores de vida, é a reação dos vasos sangüíneos que conduz a um acúmulo de líquido e de leucócitos, especialmente neutrófilos no líquido extracelular.

Estas células de defesa atuam no sentido de destruir ou bloquear o agente agressor seja ele físico, químico ou biológico (PEREIRA; BOGLIOLO, 1998).

Conforme Montenegro e Fecchio (1992), do ponto de vista funcional e morfológico, as inflamações agudas decorrem de alterações do calibre vascular que conduzem a um aumento de fluxo sangüíneo, e, caracterizam-se pelo predomínio de fenômenos exsudativos que implicam em alterações da permeabilidade vascular (micro vascularização) permitindo o acúmulo de líquido (edema) e leucócitos na região inflamada.

As respostas vasculares e celulares da inflamação aguda são mediadas por fatores químicos provenientes do plasma ou das células e desencadeados pelo estímulo inflamatório. Tais mediadores, atuando de maneira isolada, em combinações ou em seqüência, amplificam a resposta inflamatória e influenciam sua evolução (COTRAN; KUMAR; COLLINS, 2000). Assim sendo, a intensidade do processo inflamatório bem como a formação de edema está diretamente relacionada ao grau da lesão tecidual (GUYTON; HALL, 1998).

De acordo com Becker (1997), as alterações no fluxo e calibre vasculares começam pouco após a lesão e desenvolvem-se em velocidades variáveis, de acordo com a intensidade da lesão. O estímulo patogênico atua sobre a via 
sangüínea terminal das estruturas sobre as quais incide, ocasionando distúrbios vasculares e migração de fluidos plasmáticos e de células sangüíneas para os espaços intersticiais teciduais

O aumento da permeabilidade vascular levando ao extravasamento de um líquido rico em proteína (exsudato) para o interstício é o sinal característico da inflamação aguda. A perda de proteína para o plasma reduz a pressão osmótica intravascular e eleva a pressão osmótica do líquido intersticial. Juntamente com a pressão hidrostática elevada devido à vasodilatação, isso acarreta um refluxo acentuado de líquido e seu acúmulo no tecido intersticial (COTRAN; KUMAR; COLLINS, 2000). Esse aumento do líquido extravascular é denominado "edema inflamatório" (BECKER, 1997).

Em função da vasodilatação, ocorre a circulação fica mais lenta, isto decorre do aumento da permeabilidade da vascular e pelo extravasamento de líquido rico em proteína, dentre elas a albumina, para dentro dos tecidos extra vasculares.

\subsection{Azul de Evans - Teste Edemogênico}

O Azul de Evans começou a ser utilizado em trabalhos experimentais por volta de 1943 por Rawson, quando foi apresentado como um corante inócuo e desde então, tal propriedade foi comprovada em diversas pesquisas científicas (FREEDMAN; JOHNSON, 1969; LINDERKAMP, 1977; WOODS; SMITH; GRAHAM, 1988). 
Já em 1947, um estudo de Leveen e Fishman mostrou que quando inoculado via endovenosa, o Azul de Evans combina-se com a albumina de maneira reversível.

Nos anos seguintes, diversos estudos demonstraram que, após 40 horas da administração endovenosa do Azul de Evans em ratos, 90\% do corante já desaparece da circulação e que depois de 24 horas de inoculação endovenosa, ele pode ser em $30 \%$ encontrado na pele, $13 \%$ nos músculos, $12 \%$ no fígado e $9 \%$ nos ossos (CASTER; SIMON; ARMSTRONG, 1955; CLAUSEN; LIFSON, 1956).

Em 1966, Steele e Wilhelm demonstraram a combinação do Azul de Evans à albumina plasmática formando um complexo corante-albumina que pode extravasar através da barreira endotelial lesada.

Um dos estudos mais importantes acerca do teste edemogênico, foi realizado por Udaka, Takeuchi e Movat, em 1970, que realizaram uma análise físico-química para a mensuração quantitativa do aumento da permeabilidade vascular na inflamação provocado em coelhos, ratos e cobaias pela injeção subcutânea de substâncias flogógenas, em diferentes soluções, com a administração intravenosa do Azul de Evans e absorção do mesmo com o uso da formamida como solvente. A avaliação foi realizada com injeção intravenosa de $60 \mathrm{mg} / \mathrm{kg}$ de peso corporal, em coelhos e cobaias, e de $20 \mathrm{mg} / \mathrm{kg}$ de peso corporal em ratos, de uma solução de azul de Evans. Após 30 minutos da injeção do corante e do agente inflamatório, os animais eram sacrificados e suas peles excisadas, removendo fragmentos de 1.5 a $2.5 \mathrm{~cm}$ de diâmetro. Os fragmentos eram imersos em frascos com $4 \mathrm{~mL}$ de formamida e levados à estufa, por 72 a 96 horas a $45^{\circ} \mathrm{C}$ ou por 24 a 36 horas a $65^{\circ} \mathrm{C}$, para extração do corante. O líquido foi filtrado em fibras de vidro e levado ao espectrofotômetro, onde foi lida a densidade óptica no espectrofotômetro de luz a 
$620 \mathrm{~nm}$ de comprimento de onda. A magnitude da reação infamatória foi avaliada pela quantificação de corante extravasado. Os resultados mostraram que administrado nas concentrações de $60 \mathrm{mg} / \mathrm{kg}$ para os coelhos e $20 \mathrm{mg} / \mathrm{kg}$ para os ratos e o corante diluído em $4 \mathrm{~mL}$ de formamida, permitiu a quantificação pelo espectrofotômetro com sucesso do aumento da permeabilidade vascular em lesões inflamatórias induzidas com vários agentes flogógenos.

O efeito de drogas antiinflamatórias foi analisado por Swingle e Shideman (1972) nas fases exsudativa e proliferativa da reação inflamatória, induzida pelo implante de bolinha de algodão, no tecido subcutâneo de ratos, que tiveram a glândula supra-renal removida. Descreveram três fases de resposta ao implante subcutâneo que consistia de: 1 - Uma fase transexsudativa, definida como um aumento no peso úmido da bolinha que ocorre durante as primeiras três horas; 2 Uma fase exsudativa, definida como o derramamento de Azul de Evans da corrente circulatória ao redor do granuloma, ocorrendo entre 3 e 72 horas após o implante da bolinha de algodão; 3 - Uma fase proliferativa, avaliada como um aumento no peso seco do granuloma que ocorre entre 3 e 6 dias. Com relação aos efeitos das drogas antiinflamatórias foi possível observar que a dexametasona, a hidrocortisona e a indometacina, atuaram contra as fases exsudativa e proliferativa.

Garcia-Leme e Shapoval (1975) estudaram essa metodologia por meio da injeção de carragenina em patas de ratos e determinaram em 2,5\% a concentração ideal do Azul de Evans a ser administrado em testes edemogênicos e proporção de $0,1 \mathrm{~mL} / 100 \mathrm{~g}$ de massa corporal para estudos em camundongos ou ratos.

Nagem-Filho e Pereira (1976) padronizaram o teste edemogênico, preconizado por Udaka, Takeuchi e Movat (1970), estabelecendo critérios complementares de avaliação no método de exsudação de corantes vitais. O valor 
de absorbância, que traduz a proporção de corante exsudado, referente ao potencial irritativo das substâncias testadas, foi dividido em quatro graus (Quadro 2.1).

\begin{tabular}{|l|l|}
\hline $0,0000-0,1249$ & Não significante \\
\hline $0,1249-0,3010$ & Discreto \\
\hline $0,3010-0,6201$ & Moderado \\
\hline $0,6201-2,0000$ & Severo \\
\hline
\end{tabular}

Quadro 2.1 - Critérios de avaliação do potencial irritativo de substâncias segundo os valores de absorbância (A620)

Em 1977, Rutberg, Spangberg e Spangberg avaliaram se o método descrito por Udaka, Takeuchi e Movat (1970) era válido para a quantificação da permeabilidade vascular, através da injeção intradérmica de algumas soluções irrigadoras, utilizadas nos canais radiculares. Foram utilizados no experimento ratos Sprague-Dawley, que após anestesiados e tricotomizados em oito locais, receberam em seu dorso as seguintes soluções: EDTAC, Zefiran 0,1\%, lodopax 0,04\%, hipoclorito de sódio $1 \%$ e $5 \%$, peróxido de hidrogênio $3 \%$ e um agente antimicrobiano experimental. Foi aplicado $0,1 \mathrm{ml}$ das soluções testes e injetou-se o corante azul de Evans 2\% na veia dorsal peniana. Após 2 horas, os animais foram sacrificados e suas peles dorsais removidas. Com um vazador de ferro, as lesões foram recortadas, imersas em $4 \mathrm{~mL}$ de formamida e levadas por 72 horas a $45^{\circ} \mathrm{C} \mathrm{em}$ estufa. Após esse período a solução foi filtrada e a absorbância medida no espectrofotômetro, com comprimento de luz de $620 \mathrm{~nm}$. Os resultados demonstraram que tanto o hipoclorito de sódio $5 \%$ como o peróxido de hidrogênio $3 \%$ não puderam ser avaliados devido ao severo dano causado aos tecidos. Dentre as demais soluções, a mais irritante foi o EDTAC seguido do Zefiran; o hipoclorito de sódio 1\% e o lodopax foram respectivamente as menos irritantes. Um achado exclusivo no grupo do EDTAC foi o extravasamento de células vermelhas, provavelmente devido 
ao seu efeito quelante sobre o cálcio, dificultando a adesão dos eritrócitos às células endoteliais dos vasos sangüíneos.

Motta (1982) empregou duas metodologias para avaliar, em ratos, a compatibilidade de cimentos cirúrgicos que tinham ou não eugenol em sua composição. Na primeira, utilizou o Azul de Evans em tempos experimentais de 1 e 3 horas, denominando a primeira etapa de reação inflamatória imediata e a segunda de etapa da reação inflamatória crônica, implantando lamínulas de vidro e verificando aderência celular nos tempos experimentais de 4, 6, 8 e 12 dias. Os resultados levaram a concluir que em ambos os momentos da reação inflamatória o cimento sem eugenol mostrou-se mais biocompatível.

O teste edemogênico foi utilizado, também, por Alle (1985) para avaliar a ação de antiinflamatórios não esteróides nas fases imediata (1 hora) e tardia (3 horas) da inflamação aguda, tendo como agente flogógeno os produtos da placa dental.

Cantazaro-Guimarães et al. (1996) empregaram o teste edemogênico para avaliar o efeito de drogas antiinflamatórias não-esteroidais e identificaram a metodologia como adequada para o experimento. Uma suspensão de parede celular de bactérias de placa dental humana foi inoculada intradermicamente na região dorsal de ratos os quais, em seguida receberam endovenosamente, o corante azul de Evans. Transcorridos os períodos experimentais de 1/2, 1, 3 e 6 horas os animais foram sacrificados e a porção de pele azulada ao redor dos implantes foi removida e cortada com o auxílio de um vazador de ferro de $23 \mathrm{~mm}$ de diâmetro, fragmentados em pedaços pequenos, imersos em $4 \mathrm{~mL}$ de formamida por 72 horas a $45^{\circ} \mathrm{C}$ para extração do corante e as amostras foram submetidas à análise no espectrofotômetro $(630 \eta \mathrm{m})$. 
O poder flogógeno da placa dental também foi analisado por Taveira (1988) utilizando o teste edemogênico com azul de Evans, em tecido subcutâneo de ratos nos períodos de 1, 3 e 6 horas, nos períodos mais prolongados 24, 48 e 72 horas realizou a contagem diferencial de leucócitos e nos períodos de 12, 24 e 36 dias, implantou no citado tecido bolinhas de algodão embebidas em suspensões de placa dental, induzindo a formação de granuloma. Os resultados mostraram que todos os métodos foram adequados para tais estudos.

Consolaro (1991) estudou o efeito antiinflamatório da talidomida sob três metodologias: teste edemogênico com Azul de Evans, número de leucócitos circulantes, por meio de leucogramas e migração neutrofílica, por meio da implantação de lamínulas de vidro e ainda sua influência na formação de granulomas. Os resultados mostraram que todas as metodologias empregadas foram semelhantes ao avaliar que a talidomida possui efeito antiinflamatório moderado.

O Azul de Evans também foi empregado por Kerezouidis, Olgart e Edwal (1993) para avaliar a reação inflamatória produzida por estímulos elétricos no nervo alveolar inferior de ratos. A estimulação foi feita por 30 segundos na presença de um bloqueador alfa-adrenérgico. Para comprovar a efetividade do método edemogênico, o laser Doppler foi empregado no pré e pós-operatório para comparação dos resultados. Estudos relatam que a permeabilidade vascular pode ser medida através do extravasamento de corantes específicos.

Belayev (1996) realizou um estudo medindo a formação de edema em função do extravasamento do Azul de Evans ligado à albumina plasmática, após oclusão de artéria cerebral em ratos, onde a fluorescência do corante foi medida por um espectrofluorímetro, excitando-se o corante em 620 nm com sucesso. 
Guimarães et al. (1996) utilizaram o teste edemogênico para avaliar a ação dos antiinflamatórios não esteroidais (NSAIDs) ibuprofeno, sulindac, naproxeno e glucametacin. Os testes foram feitos após a indução de granulomas no dorso de ratos com agentes flogógenos obtidos a partir da placa dental. Os períodos testados foram 4, 6 e 8 dias e todas as drogas mostraram algum efeito inibidor da atividade inflamatória sendo que o sulindac mostrou-se superior aos demais seguido do ibuprofeno, naproxeno e da glutametacina.

Jönsson (1998) iniciou a quantificação por meio da espectrofotometria após o extravasamento do Azul de Evans utilizando tratamento de imagens comparadas em indução de queimaduras de pele em ratos.

Bunczak-Reeh e Hargreaves, (1998) empregaram o teste edemogênico pelo extravasamento do Azul de Evans para comprovar a eficácia de antiinflamatórios derivados do ibuprofeno. O estudo foi baseado em inflamações pulpares de molares e os resultados mostraram que conforme o grau de inflamação e a concentração da medicação empregada, alcança-se com sucesso a redução do $\mathrm{pH}$ e conseqüentemente o efeito inflamatório é diminuído.

Santa Cecília (1999) testou as propriedades físico-químicas e biológicas de uma solução experimental irrigadora de canais através dos testes: edemogênico, teste do "olho da cobaia", atividade antimicrobiana, estabilidade do $\mathrm{pH}$, concentração do cloro ativo e capacidade de dissolução de tecido orgânico. Para o teste edemogênico, foi injetado $0,6 \mathrm{~mL}$ do corante Azul de Evans na veia caudal lateral de 80 ratos Wistar. Foram divididos em 4 grupos de 20 espécimes cada, de acordo com as soluções testadas: hipoclorito de sódio a 1\% (Virex), solução experimental recém preparada, solução experimental estocada por uma semana e solução fisiológica (controle). Por via subcutânea foram injetados $2 \mathrm{~mL}$ das soluções na região dorsal e, 
decorridos os períodos de 30 minutos, 1, 3 e 6 horas, os animais foram sacrificados, suas peles excisadas e submetidas ao processo de remoção e análise espectrofotométrica do corante extravasado. O hipoclorito de sódio se mostrou o menos irritante das soluções testadas.

Reações teciduais, induzidas por alguns ácidos utilizados em endodontia, foram estudadas durante a fase exsudativa do processo inflamatório por Souza, em 1999. Para tanto, injetou-se na veia caudal lateral de ratos Wistar, 0,4 $\mathrm{mL}$ de Azul de Evans a $2 \%$ e em subcutâneo de rato na região dorsal $0,1 \mathrm{ml}$ de EDTAC 15\%, EGTA $15 \%$, ácido cítrico $15 \%$ e soro fisiológico. Após intervalos de 30 minutos, 1, 3 e 6 horas, os animais foram sacrificados e suas peles excisadas e submetidas ao processo de remoção e análise do corante extravasado pela espectrofotometria de absorção de luz a 620 ๆm. Concluiu-se que a ordem irritativa decrescente das soluções analisadas foi: EDTA, EGTA, ácido cítrico e soro fisiológico.

O efeito antiinflamatório da talidomida em comparação ao diclofenaco sódico, utilizando o teste edemogênico, foi analisado por Consolaro (1991). Foram utilizados 90 ratos divididos em 3 grupos, um para cada substância a ser testada mais um grupo controle. Dois dias antes da realização dos testes, os animais receberam doses das drogas a serem testadas ou de soro fisiológico como placebo administrado a cada 12 horas. Após a aplicação intravenosa do corante azul de Evans os animais receberam uma injeção subcutânea na região dorsal posterior de $2 \mathrm{ml}$ de solução com carragenina, para induzir reação inflamatória. Decorridos os prazos de 1/2, 1, 2, 3 e 6 horas os animais foram sacrificados e a área de edema demarcada pela coloração azul removida com o auxilio de um vazador de ferro $n^{\circ} 23$ para que o corante pudesse ser extraído em $4 \mathrm{ml}$ de formamida e submetido à 
espectrofotometria, onde foi possível observar que na permeabilidade imediata a talidomida não tem efeito anti edemogênico e sim facilita a exsudação plasmática.

O potencial irritativo das soluções de gluconato de clorexidina a $2 \%$, hipoclorito de sódio a $1 \%$ e uma associação destes irrigantes, em que a concentração da clorexidina foi alterada para $0,2 \%$, foi avaliado por Pasternak Jr, Tavares e Perin (2002). Após a inoculação das substâncias no tecido subcutâneo de ratos da linhagem Wistar, os autores compararam a capacidade dessas substâncias de provocar exsudação plasmática de corantes vitais. Os resultados foram obtidos por leitura ótica em um espectrofotômetro, que permitiu constatar que a combinação de hipoclorito de sódio a $1 \%$ com gluconato de clorexidina a $0,2 \%$ foi significativamente menos agressiva quando comparada às soluções usadas individualmente.

Bianconcini (2001) avaliou a citotoxidade do digluconato de clorexidina e do hipoclorito de sódio em subcutâneo de ratos durante o processo inflamatório agudo, na fase exsudativa, em tempos experimentais de 30 minutos, 6 horas e 24 horas. 0 pico da absorção de luz empregada foi 620 nm. Concluiu-se que o hipoclorito mostrou-se menos irritante que as clorexidina aos 30 minutos e 24 horas.

Staveren et al. (2001), realizaram um estudo utilizando a espectroscopia de fluorescência para diferenciar tecido normal e pré-maligno. Utilizaram os modelos animais de lesão pré-maligna em pele de ratos induzida por radiação UVB, tumorsólido transplantado para pele de ratos e lesão pré-maligna em mucosa palatina de ratos. Os espectros de fluorescência foram registrados in vivo, sendo que, a obtenção dos mesmos deu-se por um corante não tóxico denominado Ethyl Nile Blue A (600 ๆm excitação, 665-900 nm emissão), o qual permitiu a identificação das regiões em estudo em tempos distintos. 
Brancaleon et al. (2001), estudaram a fluorescência in vivo de pacientes diagnosticados com melanoma de pele, e compararam com a fluorescência da pele normal. Verificaram emissão de fluorescência do triptofano, a qual foi mais intensa no tumor do que no tecido (pele) normal, provavelmente, devido ao maior espessamento e hiperproliferação que esta apresenta. Observaram, ainda, fluorescência de colágeno, o qual se apresentou reduzido no tumor, quando comparado com o tecido normal circundante, devido à liberação de enzimas, pelo tumor, que degradam o tecido conjuntivo.

No ano seguinte Ribeiro (2002) avaliou a intensidade da reação inflamatória aguda do tecido subcutâneo de ratos, quando em contato com a pasta de hidróxido de cálcio e o digluconato de clorexidina a $2 \%$, empregando, também o teste edemogênico. Após a aplicação do corante azul de Evans, pela veia caudal, foram injetadas na região dorsal dos animais as substâncias a serem testadas na proporção de 0,2 mL/100 mg de peso corporal. Decorridos os períodos de 1, 3, 6 e 24 horas a área demarcada pelo corante foi removida, preparada e analisada no espectrofotômetro. Os resultados demonstraram que o digluconato de clorexidina a $2 \%$ foi mais irritante em todos os períodos experimentais.

Canova et al. (2002) avaliaram, por meio do teste edemogênico, a reação tecidual de quatro cimentos endodônticos: Endométhasone, Sealapex, Sealer Plus e Sealer 26. Para tanto, foram utilizados 48 ratos que receberam, anteriormente à implantação dos cimentos, recentemente manipulados, uma injeção intravenosa do corante Azul de Evans, na proporção de 0,2 mL para cada $100 \mathrm{~g}$ de massa corporal. A quantidade de cimento injetado foi padronizada, utilizando uma seringa descartável adaptada a um parafuso que desempenhava o papel de êmbolo rosqueável, sendo preconizado duas voltas completas do parafuso para a injeção do 
cimento através de uma agulha 25X8. Decorridos os prazos de 3 e 6 horas os animais foram sacrificados e as áreas demarcadas pelo extravasamento do corante removida com o auxilio de um vazador de ferro $n^{\circ} 23$, para que então pudesse ser extraída em $4 \mathrm{~mL}$ de formamida mantidas em estufa a $45^{\circ} \mathrm{C}$ por 72 horas. Na análise dos resultados foi possível observar que o Sealer 26 e o Sealapex apresentaram quantidade de exsudato semelhante entre si, sendo ambos inferiores ao Sealer Plus e Endométhasone que também apresentaram resultados semelhantes.

Melo (2002) relatou que o aumento permeabilidade vascular pode ser quantificado através do extravasamento de corantes específicos e utilizou o Azul de Evans para análise dinâmica do extravasamento da albumina plasmática para um edema induzido por carragenina através de espectroscopia de fluorescência, onde o pico da formação do edema foi determinado em função da emissão de fluorescência do Azul de Evans. Os resultados obtidos foram comparados com aqueles obtidos através da técnica convencional, a técnica da albumina marcada com 125I. As medidas de fluorescência foram realizadas em ratos Wistar por um espectrofluorímetro composto de um laser de nitrogênio bombeando um laser de corante que emite radiação em 458 nm. Observou-se que o Azul de Evans presente no edema emitiu um pico de fluorescência em 680 nm e esta aumentou em função do tempo. Os resultados mostraram que o Azul de Evans permite analisar qualitativamente e quantitativamente a dinâmica do edema, e que, existe correlação entre os resultados de ambas as técnicas.

Brunini (2001) avaliou as reações do tecido conjuntivo subcutâneo de ratos à inoculação dos cimentos endodônticos Endométhasone, AH Plus e Sealer 26 empregando teste edemogênico em períodos de 1, 3 e 6 horas. Os resultados indicaram que houve exsudação plasmática frente a todos os cimentos obturadores 
e que o cimento Sealer 26 mostrou-se o mais irritante para todos os períodos experimentais.

Trujillo Junior et al. (2003) realizaram pesquisa para avaliar in "in vivo" o potencial irritativo do ácido cítrico em diferentes concentrações, nos tempos de, 1/2, 1, 3 e 6 horas, pela técnica de exsudação de corantes vitais. Inicialmente (1/2 hora) todas as concentrações foram irritantes ao tecido conjuntivo e no decorrer do tempo, elas se diferenciam entre si. Com relação à concentração, as soluções de ácido cítrico, a $1 \%$ e $10 \%$, foram menos irritantes que as demais. Houve uma semelhança de comportamento entre as soluções a $5 \%$ e $25 \%$, nos períodos de tempo de 1,3 e 6h, sendo as mais irritantes. A solução menos irritante foi o ácido cítrico a $1 \%$.

Silva, Almeida e Sousa (2004) avaliaram o potencial irritativo da própolis, Casearia sylvestris, Otosporin e soro fisiológico (controle). Foram utilizados 28 ratos machos da linhagem Wistar. Os animais foram anestesiados e, em seguida, receberam a injeção do corante azul de Evans (2\%) por via intravenosa na veia caudal. Em quatro pontos predeterminados e depilados da região dorsal de cada animal, foram injetados $0,1 \mathrm{~mL}$ das substâncias teste. Os animais foram sacrificados meia, uma, três e seis horas após a injeção das substâncias, e cada porção de pele contendo a lesão foi colocado em frascos contendo formamida, que foram incubados a $45^{\circ} \mathrm{C}$ por $72 \mathrm{~h}$. Após esse período, as amostras foram filtradas e submetidas à análise em espectrofotômetro. Os maiores índices do corante extraído foram observados no período de 3 horas, caracterizando assim, o pico do processo inflamatório. A própolis foi a substância que apresentou menor potencial irritativo. Os autores concluíram que o estudo mostrou que substâncias naturais podem ser utilizadas como alternativas para tratamentos endodônticos. 
Gehlen et al. (2004) Constaram a presença do azul de Evans na córnea normal estipulando o período de tempo de concentração máxima do corante após inoculação endovenosa e estudando a permeabilidade vascular em modelo animal da inflamação corneal induzida por queimadura química por meio de injeção do Azul de Evans. Cinqüenta coelhos foram divididos em 3 grupos: No primeiro (25 animais): injetou-se $20 \mathrm{mg} / \mathrm{kg}$ de azul de Evans e os animais foram sacrificados após 8, 10, 12, 14 e 16 horas. Retirou-se a córnea e quantificou-se o corante por meio de micrométodo espectrofotométrico. No grupo II, 15 animais receberam o corante e após 10 horas, fragmentou-se centralmente o tecido com trépanos de 6 , 8 e $10 \mathrm{~mm}$. Procedeu-se à extração do azul de Evans da mesma forma que no grupo I. No último grupo, induziu-se queimadura na córnea do olho direito de 10 animais com $\mathrm{NaOH}$. Cinco dias após o procedimento, os animais foram sacrificados, sendo que, 10 horas antes do sacrifício, foi inoculado o Azul de Evans para que posteriormente fosse possível quantificá-lo. A córnea esquerda serviu como controle. Os autores concluíram que foi possível quantificar o Azul de Evans pela primeira vez na córnea de coelhos e constataram que, após 10 horas de inoculação endovenosa, o corante atingiu seu pico de concentração no tecido. Além disso, afirmaram que o azul de Evans serve como bom método de quantificação da permeabilidade vascular alterada na córnea de coelhos. 


\subsection{Biocompatibilidade - outros estudos}

Todos os cimentos escolhidos para esta pesquisa podem ser considerados uma nova geração de materiais obturadores endodônticos. Diferentes entre si basicamente pela sua base de composição veremos a seguir alguns relatos de estudos acerca da sua biocompatibilidade.

Bombana (1981) estudou a reação do tecido conjuntivo de ratos frente à presença do cimento de $\mathrm{N}$-Rickert, com base em óxido de zinco e eugenol em sua composição, dentro e fora de tubos de polietileno implantados subcutaneamente. Os tempos experimentais foram 24 horas, 07,14 e 28 dias, nos quais foram realizados exames histológicos cujas lâminas permitiram concluir que o cimento foi bem tolerado pelo tecido conjuntivo e que a reparação se deu mais rapidamente quando o mesmo não estava em contato direto com o tecido.

Kolokuris et al. (1996) estudaram a biocompatibilidade em tecido conjuntivo de ratos de um cimento com base de ionômero de vidro, o Ketac-Endo e o TubliSeal. 44 ratas Wistar tiveram tubos de Teflon preenchidos com os cimentos implantados subcutaneamente em seu dorso. Os implantes foram removidos nos tempos experimentais de $5,15,60$, e 120 dias, quando foram fixados e estudados histologicamente. Os resultados mostraram que no quinto dia o Ketac-Endo mostrou-se atividade irritante ao tecido conjuntivo, quando linfócitos e macrófagos foram observados. A intensidade da reação diminuiu a partir do décimo quinto dia, assim progredindo nos demais tempos experimentais. Por outro lado, o Tubli-Seal apresentou inflamação severa com áreas de necrose entre o quinto e o décimo quinto dia, permanecendo irritante nos demais períodos. 
Brito et al. (2000) verificaram o efeito do óleo de copaíba no colo uterino de ratas ooforectomizadas. Foram utilizadas 120 ratas adultas submetidas a ooforectomia bilateral e posteriormente mantidas em gaiolas por um período de 20 dias antes de iniciar a aplicação das substâncias distribuídas em 4 grupos: óleo de copaíba, óleo de milho, água e um grupo sem tratamento. Os tempos experimentais foram 7, 14 e 21 dias. Durante cada período, as substâncias foram administradas via vaginal na dose de 0,3 $\mathrm{mL}$, diariamente, uma vez ao dia. Em cada tempo experimental 5 animais de cada grupo era sacrificado e os epitélios analisados. Os resultados permitiram aos autores observar que em todos os animais do grupo do óleo de copaíba apresentaram epitélio exuberante, estratificado pavimentoso queratinizado, lâmina própria com tecido conjuntivo denso, rico em fibroblastos, fibras colágenas, inúmeros vasos sanguíneos e alguns leucócitos.

Veiga Jr. et al. (2001) estudaram in vivo a composição de oito tipos de óleos derivados da copaíba comercializados em supermercados. Todos eles utilizados na região amazônica como antiinflamatórios. As análises foram feitas por cromatografia e espectrofotometria, de acordo com a inibição da bradicinina e diminuição do edema após sua indução através da carragenina. Dentre os elementos testados, todos mostraram algum efeito quanto à inibição da formação do edema, entretanto, alguns se mostraram muito superiores. Além disso, os autores concluíram que havia falta de padronização na produção dos óleos e muitas adulterações e suas composições.

Schwarze, Leyhausen e Geurtsen (2002), pesquisaram in vitro a citotoxidade de diversos cimentos endodônticos no período de 1 hora. Os cimentos escolhidos foram Apexit, Roekoseal, AH Plus, Ketac Endo, Endomethasone. Para tanto, raízes 
de dentes humanos extraídos foram obturadas com condensação lateral e colocadas em contato com fibroblastos originados de ligamentos periodontais. Todos os cimentos mostraram-se citotóxicos nesse períodos, mas apenas o Endométhasone alterou o metabolismo das células.

Em 2003, Nassri, Lia e Bombana analisaram a compatibilidade biológica dos cimentos Sealapex e Apexit, a reação inflamatória tardia foi analisada com a implantação de tubos de polietileno preenchidos com os cimentos no tecido subcutâneo de ratos. Os tempos experimentais para o sacrifício e remoção das amostras de tecidos nos animais foram 7, 21 e 45 dias. Os cortes histológicos corados com HE possibilitaram observar intensa atividade macrofágica com os dois cimentos, sendo que o cimento Apexit mostrou reação tecidual mais agressiva e que o Sealapex mostrou-se superior com relação à evolução da reparação tecidual.

Bouillaguet et al. (2004) estudaram a citotoxidade dos cimentos endodônticos Pulp Canal Sealer, RoekoSeal, TopSeal e EndoREZ. Para tanto, foram confeccionados seis discos iguais de $1 \times 10 \mathrm{~mm}$ de cada cimento os quais foram colocados em contato direto com culturas de células de fibroblastos durante três tempos experimentais, 24,48 horas e 1 semana. Os resultados mostraram diferenças significativas entre quatro cimentos, as quais aumentaram também de acordo com o tempo. Os pesquisadores concluíram que o RoekoSeal foi o material menos citotóxico dentre os cimentos testados.

Miletic et al. (2005) estudaram in vitro com culturas de células de fibroblastos a citotoxidade dos cimentos RoekoSeal e $\mathrm{AH}$ Plus. Os tempos experimentais foram 1, 24, 48 horas e 7 dias com cinco dias de incubação. Depois disso, o número de células viáveis foi contado eletronicamente. $\mathrm{O}$ cimento $\mathrm{AH}$ Plus mostrou-se 
significativamente mais citotóxico em todos os períodos quando comparado ao RoekoSeal.

Key, Rahemtulla e Eleazer (2006) compararam a citotoxidade dos sistemas Resilon/Epiphany, Guta-percha/Cimento de Grossman e Thermaseal/Sealapex usando fibroblastos provenientes de gengiva humana. Os tempos experimentais foram 1 e 24 horas e os fibroblastos foram corados com Azul de Trypan para observar o números de células não viáveis. Com relação aos cones, o Resilon mostrou-se semelhante à guta-percha e o Epiphany menos citotóxico que o Cimento de Grossman em ambos os períodos. Por outro lado, o Epiphany foi mais citotóxico que o Sealapex no período de 1 hora, porém menos citotóxico no período de 24 horas. Os autores concluíram que o Resilon foi o material menos citotóxico e o Epiphany o mais citotóxico dentre os materiais testados.

Bouillaguet et al. (2006) pesquisaram a citotoxidade de discos dos cimentos AH Plus, Epiphany e GuttaFlow em contato com culturas de células em dois tempos experimentais, 24 e 72 horas. Os resultados mostraram que todos os materiais têm poder citotóxico e que este aumenta conforme os tempo. Além disso, o GuttaFlow mostrou-se menos citotóxico que os outros dois cimentos no período de 72 horas. Os pesquisadores concluíram que é necessário desenvolver novos materiais que tenham melhores propriedades adesivas e biocompatíveis.

Sousa et al. (2006) avaliaram in vivo a biocompatibilidade dos cimentos $\mathrm{AH}$ Plus, EndoREZ e Epiphany. Para tanto, 30 porcos linhagem guinea, que receberam implantes dos materiais testados na região de sínfise. Os tempos analisados foram 4 e 12 semanas. Após esses períodos, os animais eram sacrificados e a reação inflamatória analisada histologicamente. Os resultados mostraram reação severa em 
ambos os períodos para o EndoREZ, já no grupo do AH Plus, a reação decresceu de severa para moderada nos diferentes períodos, enquanto o grupo do Epiphany não apresentou qualquer reação inflamatória, além de demonstrar formação óssea. Assim, os autores concluíram que o Epiphany mostrou-se o melhor material dentre os testados.

Garrido et al. (2006) publicaram estudo in vivo avaliando a biocompatibilidade de alguns cimentos endodônticos após obturarem dentes de cães com Endofill, Sealer 26, AH Plus e Cop Endo. Em tempos experimentais de 21,45 e 90 dias, os animais eram sacrificados e análises histológicas, qualitativas-quantitativas realizadas em lâminas coradas com HE. Os resultados mostraram melhor padrão de tolerância tecidual apical com os cimentos Cop Endo e AH Plus.

Susini et al. (2006) estudaram a citotoxidade dos sistemas Epiphany, Roeko Seal e Sealite lançando mão de 30 dentes que foram seccionados na junção cemento-esmalte, esterilizados e em seguida, instrumentados e obturados com condensação lateral. Após mantidos incubados a 37 graus até a presa final de cada cimento, os ápices das raízes foram colocados em contato com $1 \mathrm{~mL}$ de meio de cultura MEM nos tempos experimentais 1, 2, 7 e 30 dias, sendo que o meio de cultura era diariamente renovado. Passadas 24 horas do contato entre o meio e as raízes, a citotoxidade era avaliada pelo método do contato com fibroblastos de ratos. Não houve diferença estatisticamente significante entre os cimentos nos períodos 7 e 30 dias. O Epiphany mostrou-se o material menos citotóxico nos períodos 1 e 2 dias.

Koch e Brave (2006) afirmaram que o ionômero de vidro apresentava biocompatibilidade maior, além de outras propriedades físicas superiores à de outros 
materiais empregados na obturação endodôntica. Seus relatos iniciam-se com base na aplicabilidade dos cimentos ionoméricos na área da Dentística Restauradora, afirmando sua capacidade de manter-se adesivo mesmo em meio úmido por conta de suas reações iônicas. Os mesmos também afirmaram como sendo positiva a propriedade de não ser reabsorvível desses cimentos. Tal propriedade, segundo os autores, faz com que cimentos com essa base sejam comumente utilizados na área da Medicina, especificamente em cirurgias ortopédicas.

Fisher, Berzins e Bahcall (2007) publicaram estudo comparando a adesividade dos cimentos endodônticos Pulp Canal Sealer EWT, AH Plus, Epiphany, Activ GP e EndoREZ por meio de teste push-out. Foram utilizados 25 dentes humanos unirradiculares que foram instrumentados mecanicamente e obturados de acordo com as instruções dos fabricantes. Os resultados mostraram o grupo do cimento AH Plus superior significantemente, seguido dos grupos do Pulp Canal Sealer e ActiV GP sem significância entre si e melhores significativamente que os grupos Epiphany e EndoREZ.

Onay, Ungor e Ozdemir (2007) avaliaram in vivo, a biocompatibilidade do Epiphany em tecido conjuntivo de 36 ratos Wistar. A metodologia empregada foram tubos de teflon preenchidos com o cimento implantados em quarto ponto no dorso dos animais. O grupo controle foi feito com tubos vazios e os tempos experimentais foram 1, 4, e 8 semanas para posterior estudo histológico. Os tempos, de acordo com os resultados, não mostraram diferenças significativas e o pico da intensidade inflamatória foi maior no período de quatro semanas, reduzindo continuamente com o passar do tempo. Os autores concluíram que o material testado é biocompatível. 
Monticelli et al. (2007), avaliaram o selamento apical contra infiltração bacteriana de S. Mutans por um período de 100 dias dos cimentos AH Plus, ActiV GP e GuttaFlow e concluíram que os dois cimentos que utilizam a técnica do coneúnico (ActiV GP e GuttaFlow), produziram selamento apical semelhante ao produzido pelo $\mathrm{AH}$ Plus com a técnica de compactação vertical da guta-percha. Em relação ao selamento coronário estes dois sistemas mostraram-se inferiores ao $\mathrm{AH}$ Plus.

Merdad et al. (2007) estudaram a citotoxidade dos sistemas de obturação Epiphany e da guta percha com AH Plus. O método empregado foi o contato direto com cultura de células de discos de resilon e de guta-percha cimentos em ao outro com os cimentos em questão. Os discos foram colocados em contato direto com células HeLa e incubados por duas horas. A análise dos resultados mensurados de acordo com os halos de inibição permitiu aos autores concluir que ambos os sistemas apresentaram graus de citotoxidade semelhantes.

Lodiene et al., em 2007, objetivaram comparar a toxicidade de cimentos endodônticos de diferentes bases. resina de metacrilatos, resina epóxica e silicones. Os cimentos escolhidos foram o AH Plus, EndoREZ, RoekoSeal e Epiphany, os quais foram preparados e colocados em contato direto com fibroblastos de ratos. Os resultados mostraram o cimento à base de resina de metacrilatos (Epiphany) severamente tóxico enquanto mostraram ausência de toxicidade frente aos cimentos RoekoSeal e EndoREZ. O AH Plus manteve-se com toxicidade intermediária frente aos demais cimentos.

Eldeniz et al. (2007) estudaram os efeitos tóxicos dos cimentos endodônticos RC Sealer, Epiphany, EndoREZ, GuttaFlow, Acroseal, AH Plus, RoekoSeal e Apexit. 
A metodologia empregada utilizou culturas de células de fibroblastos de gengiva humana e uma linha de fibroblastos de ratos. Foram confeccionados cilindros de 4,4 x $3 \mathrm{~mm}$ de cada cimento mantidos em placas de Petri em meio úmido com os meios de cultura a 37 graus por 7 dias. Posteriormente, por meio de microscopia, os halos foram observados e os seguintes resultados encontrados: Os cimentos resinosos Epiphany e EndoREZ, além daqueles com base em hidróxido de cálcio, Apexit e Acroseal mostraram-se significantemente menos citotóxicos que os demais cimentos em ambos os meios de cultura. Os fibroblastos de ratos foram mais sensíveis diante dos cimentos Apexit e EndoREZ. O RC Sealer e o AH Plus mostraram-se moderados diante das células humanas, além deste último parecer induzir a formação celular. O GuttaFlow foi o menos citotóxico dentre as substâncias testadas e os autores concluíram que a toxicidade pode variar de acordo com o meio de cultura utilizado mas que o RC Sealer e o GuttaFlow são os cimentos menos citotóxicos dentes os estudados.

Tanomaru-Filho et al. (2008), compararam a radiopacidade de três cimentos com base de hidróxido de cálcio; Acroseal, Sealapex e Sealer 26, um com base em ionômero de vidro; ActiV GP e um com base de óxido de zinco e eugenol; Intrafill. Os testes foram realizados por meio de análise de imagens radiográficas obtidas com raios-X digital e analisadas por um software específico. Os resultados mostraram que o Intrafill era o cimento mais radiopaco, seguido do Sealer 26, Acroseal e o ActiV GP respectivamente. Sendo que o último não atendeu as normas ISO mínimas recomendadas. 
Baseados nesta revisão de literatura entendemos como interessante, aplicar o método do teste edemogênico para avaliar a biocompatibilidade dessa nova geração de cimentos endodônticos em suas diversas bases. 
PROpOSIGAO 


\section{PROPOSIÇÃO}

Este estudo se propôs a avaliar, in vivo, o desempenho de cinco cimentos endodônticos (ActiV GP, AH Plus, Biosealer, RealSeal e RoekoSeal) frente à resposta tecidual inflamatória subcutânea, em três intervalos de tempo (6, 12 e 24h). 
MATERIAL E MÉTODOS 


\section{MATERIAL E MÉTODOS}

Inicialmente, foi realizado um piloto para determinar o "n" ideal e o projeto final aprovado pelo Comitê de Ética em Pesquisa - Subcomissão de Bioética de Animais da Faculdade de Odontologia da Universidade de São Paulo (Anexo A).

Foram utilizados 75 ratos machos, linhagem Wistar, "Rattus novergicus", pesando em média, $350 \mathrm{~g}$ cada e com idade mínima de 03 meses, que foram cedidos pelo Biotério do Conjunto das Químicas da Universidade de São Paulo (Figura 4.1).

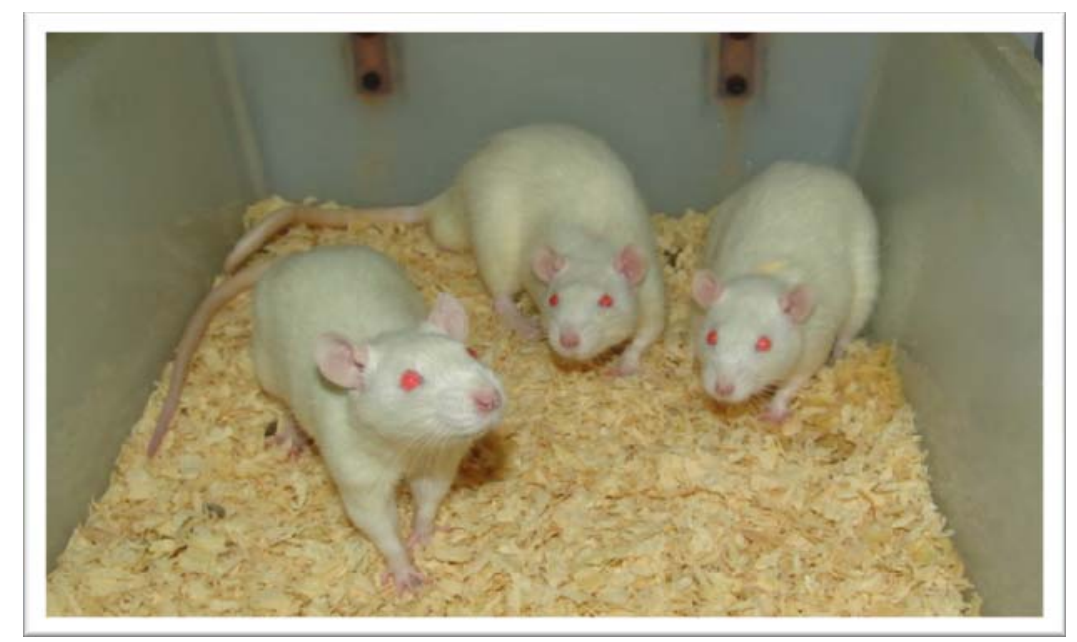

Figura 4.1 - Ratos Wistar utilizados no experimento

Cada animal possuía uma ficha individual, onde eram anotados os dados desde o início dos procedimentos até a leitura final dos resultados (Anexo B). 
Após serem anestesiados por administração subcutânea de cloridrato de quetamina (100 mg/kg) e cloridrato de xilazina (10 mg/kg), (Figuras 4.2 e 4.3) os animais receberam injeção intravenosa de Azul de Evans 2,5\% (Evan's Blue Merck, Alemanha), na proporção de $0,1 \mathrm{~mL}$ da solução para $100 \mathrm{~g}$ de massa corporal, em sua veia lateral caudal. Para tal procedimento foi utilizada uma seringa do tipo insulina (Plastipak - Becton Dickinson) (Figura 4.4).

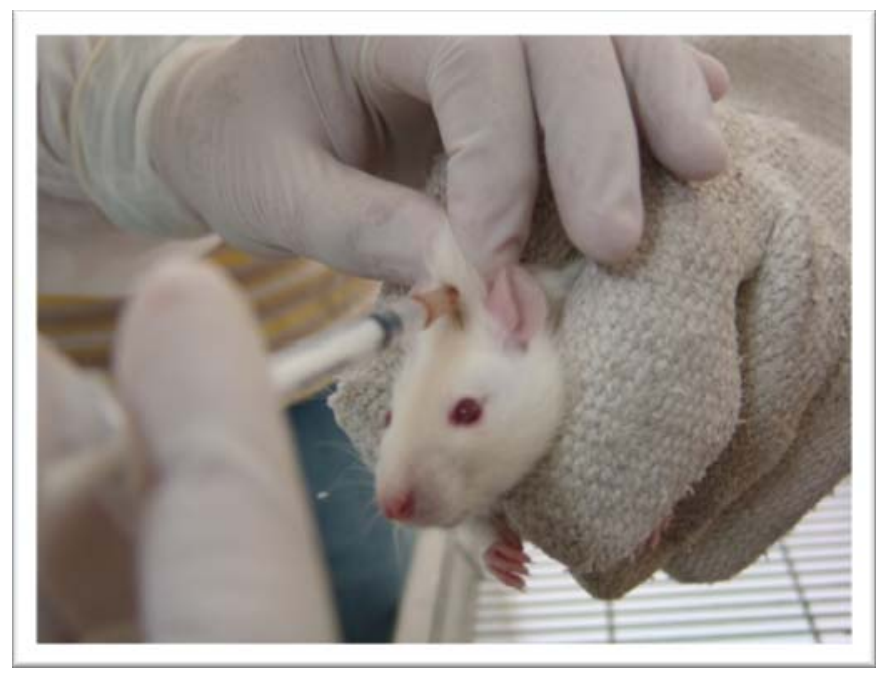

Figura 4.2 - Momento da anestesia dos animais
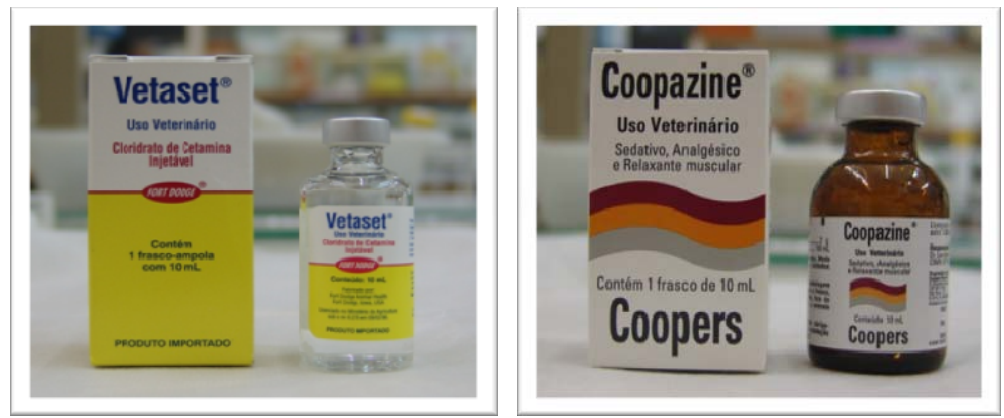

Figura 4.3 - Soluções anestésicas administradas 

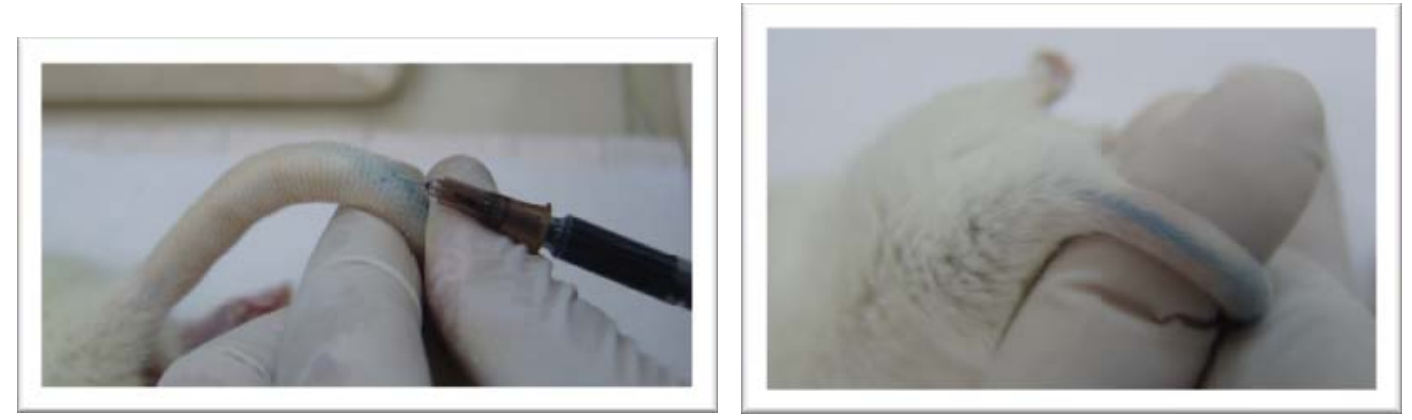

Figura 4.4 - Momento da administração do Azul de Evans

Em seguida, o dorso dos animais eram tricotomizados (Figura 4.5) e desinfectados com álcool iodado para receber os materiais a serem testados. Duas perfurações eram feitas na linha central do dorso com auxílio de uma agulha (Plastipak - Becton Dickinson), para afastar a região que receberia o cimento de uma área irritada (Figura 4.6).

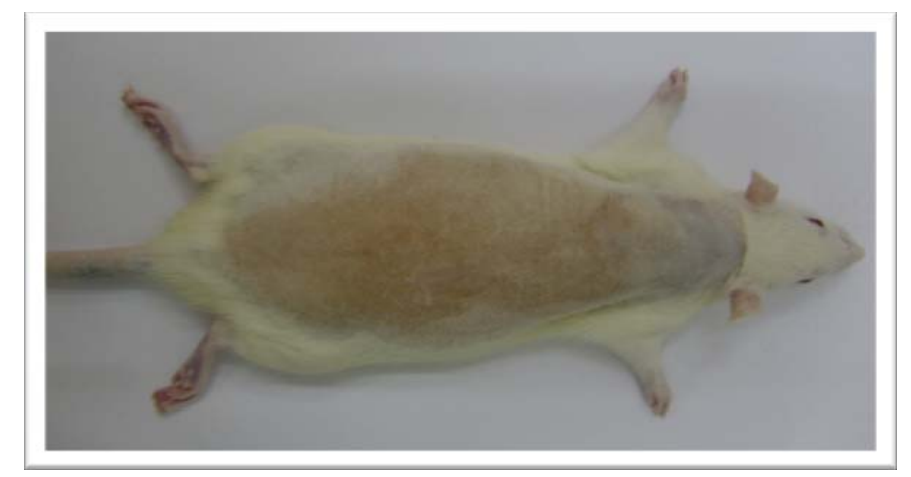

Figura 4.5 - Animal após tricotomia

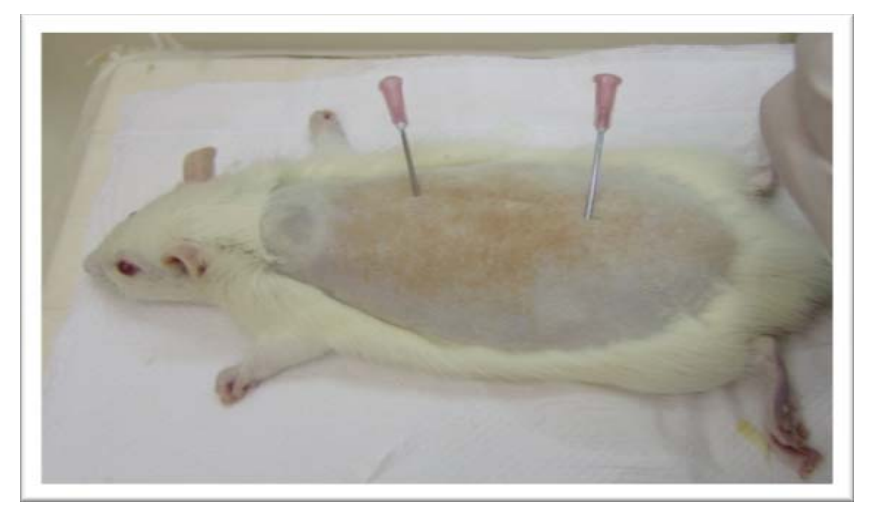

Figura 4.6 - Perfurações feitas para inserção do cateter com cimentos 
Através dessas perfurações, com auxílio de um cateter no. 22 (BDAngiocath), uma quantidade padronizada em $0,15 \mathrm{~mL}$ do cimento recém espatulado de acordo com as especificações do fabricante era levada ao tecido conjuntivo subcutâneo da região dorsal (Figuras 4.7 e 4.8).
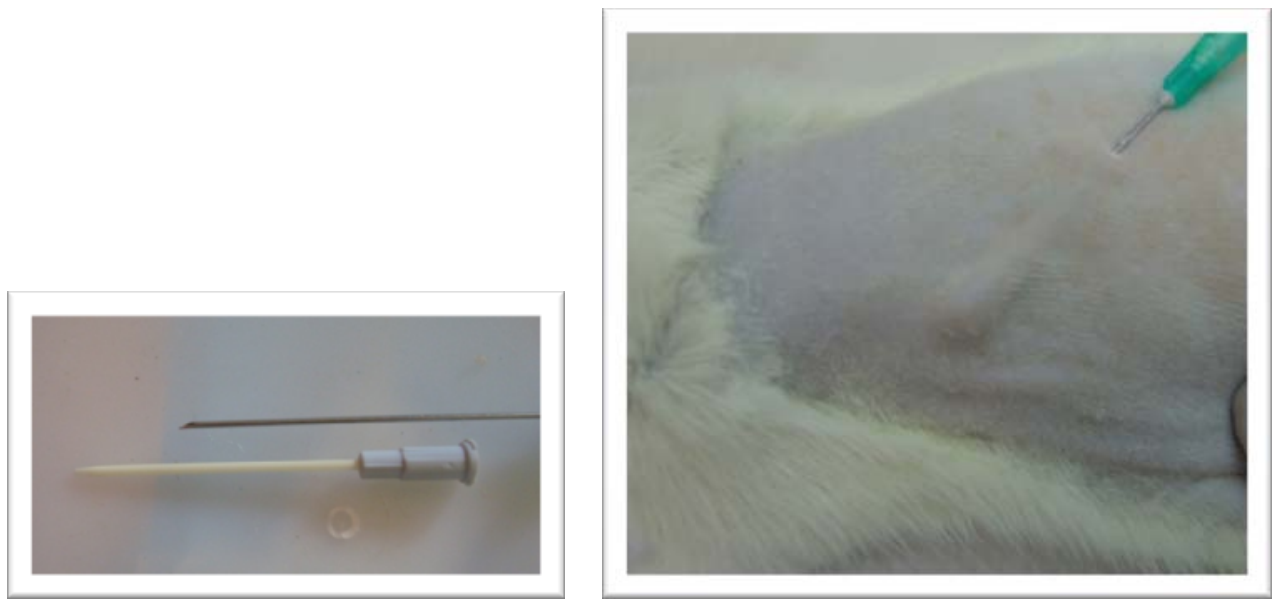

Figuras 4.7 e 4.8 - Cateter utilizado para auxílio na inserção dos cimentos e momento da injeção

Cada animal recebia 04 doses de cimentos (1 por quadrante), sempre obedecendo a mesma seqüência de inserção. Ao final, cada tempo experimental continha 20 amostras de cada um dos materiais como a seguir (Quadro 4.1).

\begin{tabular}{|l|l|l|l|}
\hline \multicolumn{1}{|c|}{$\begin{array}{c}\text { Cimentos I tempo } \\
\text { Para cada tempo experimental foram utilizados } 25 \\
\text { animais }\end{array}$} & 6h & 12h & 24h \\
\hline G1 - ActiV GP (Brasseler - USA) (Figura 4.9) & $n=20$ & $n=20$ & $n=20$ \\
\hline G2 - Biosealer (ainda fora de comercialização) (Figura 4.10) & $\mathrm{n}=20$ & $\mathrm{n}=20$ & $\mathrm{n}=20$ \\
\hline G3 - Real Seal (SybronEndo - USA) (Figura 4.11) & $\mathrm{n}=20$ & $\mathrm{n}=20$ & $\mathrm{n}=20$ \\
\hline G4 - RoekoSeal (Roeko - Germany) (Figura 4.12) & $\mathrm{n}=20$ & $\mathrm{n}=20$ & $\mathrm{n}=20$ \\
\hline G5 - AH Plus Dentsply - Germany) (Figura 4.13) & $\mathrm{n}=20$ & $\mathrm{n}=20$ & $\mathrm{n}=20$ \\
\hline
\end{tabular}

Quadro 4.1 - Grupos experimentais e número de amostras por tempo experimental 


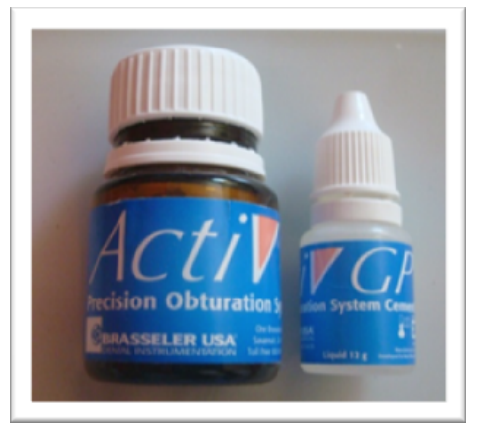

Figura 4.9 - Cimento ActiV GP (Brasseler- USA)

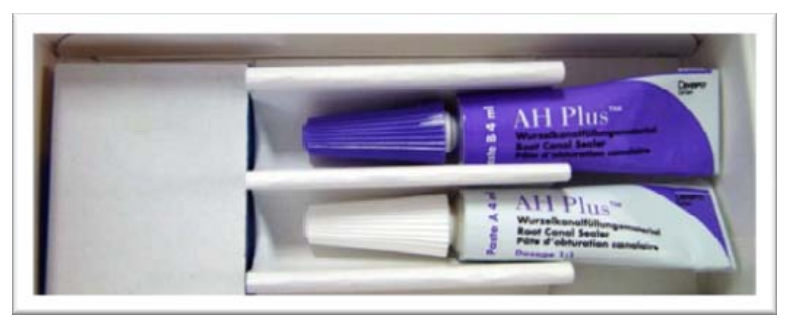

Figura 4.10 - Cimento AH Plus (Dentsply - Germany)

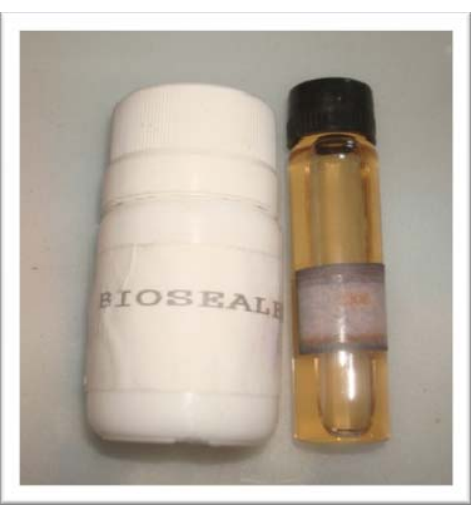

Figura 4.11 - Cimento Biosealer (em processo de legalização do fabricante)

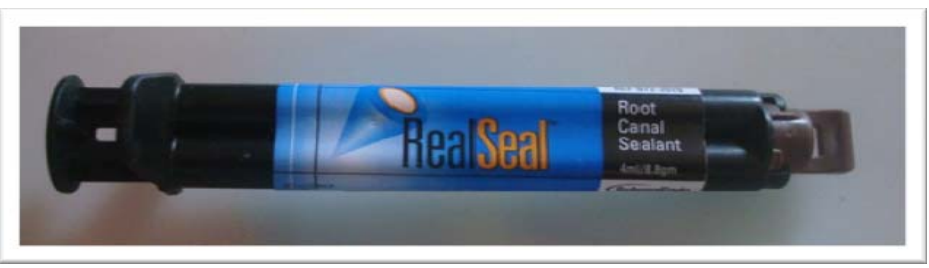

Figura 4.12 - Cimento RealSeal (SybronEndo - USA)

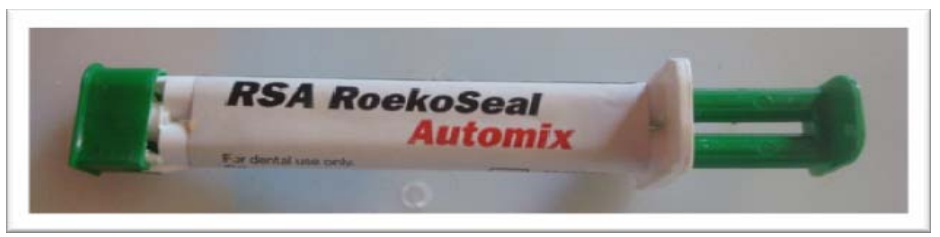

Figura 4.13 -Cimento RoekoSeal (Roeko - Germany) 
Decorridos os períodos experimentais, os animais foram sacrificados por dose excessiva de anestésico.

A pele dorsal foi excisada com o auxilio de bisturi e tesoura (Figura 4.14). Após a remoção do tecido dorsal do animal, os cimentos injetados podiam ser observados, (Figura 4.15) e a região em volta dele, removida de modo padronizado, por meio do vazador de ferro (Krause) com diâmetro de $15 \mathrm{~mm}$ (Figuras $4.16 \mathrm{a}$ 4.18).

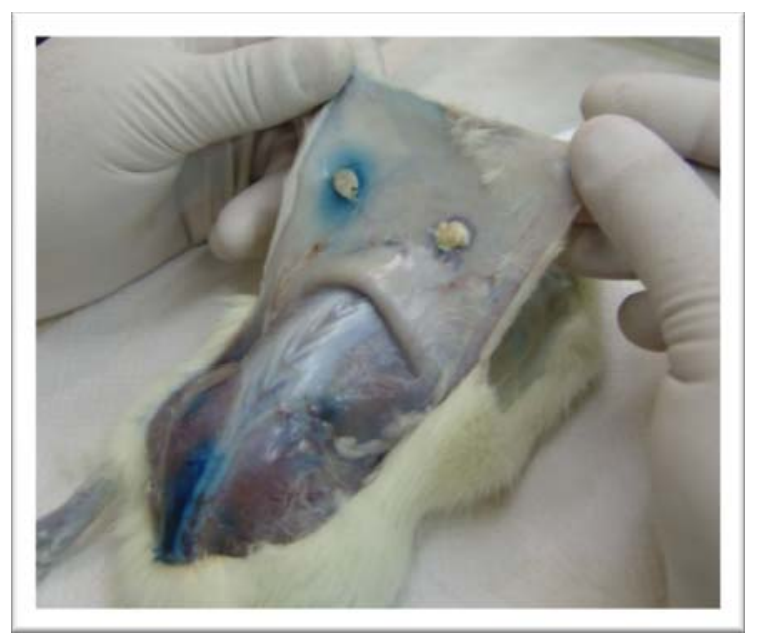

Figura 4.14 - Momento da remoção do tecido dorsal dos animais
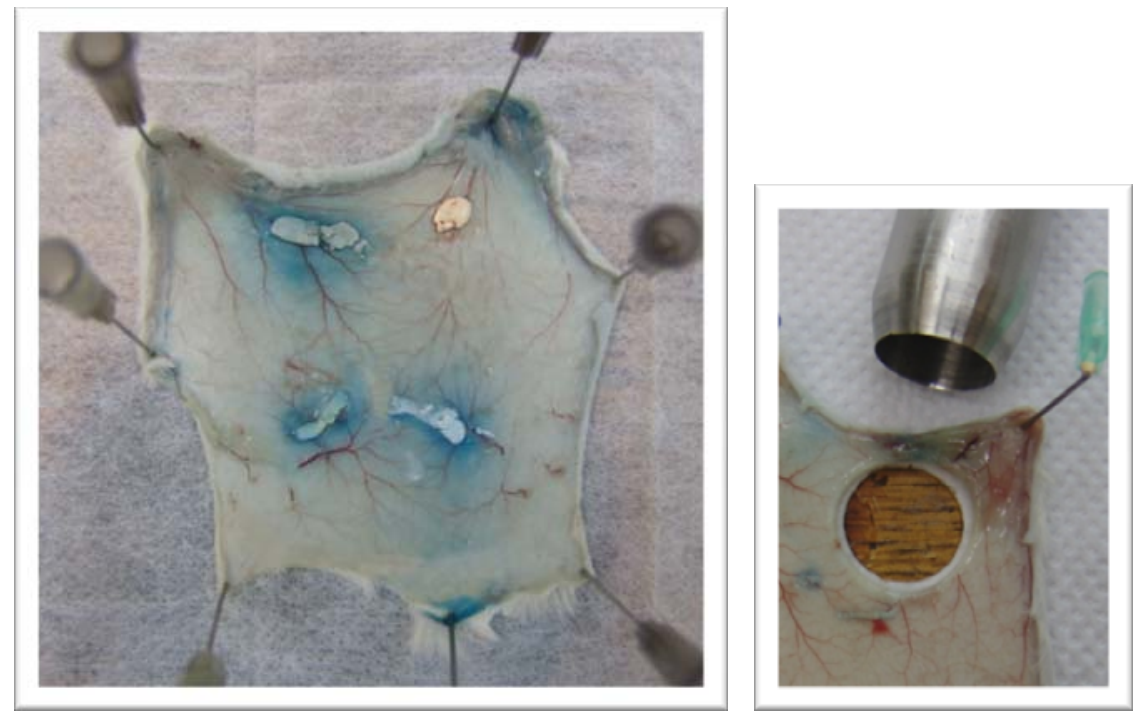

Figuras 4.15 e 4.16 - Pele dorsal removida e fixada à tábua cirúrgica e momento da remoção do fragmento com vazador de ferro 


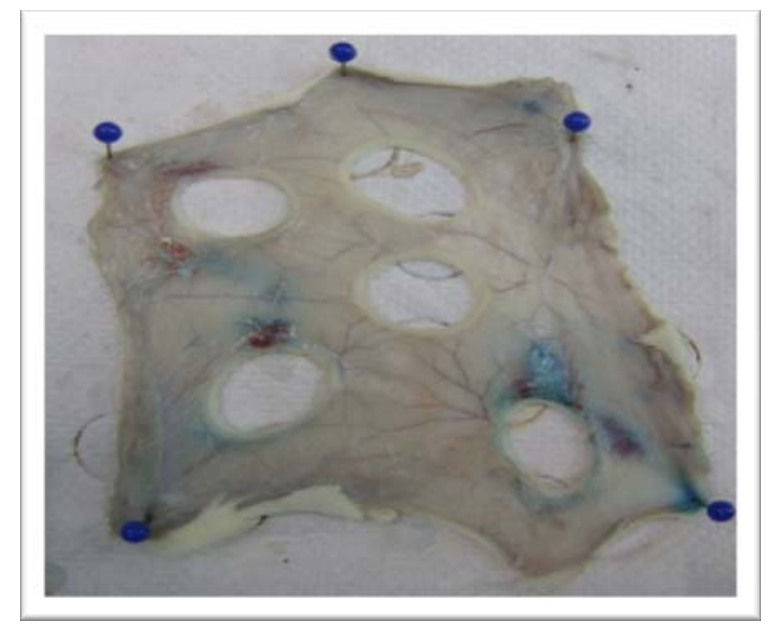

Figura 4.17 - Pele dorsal com todas as amostras removidas
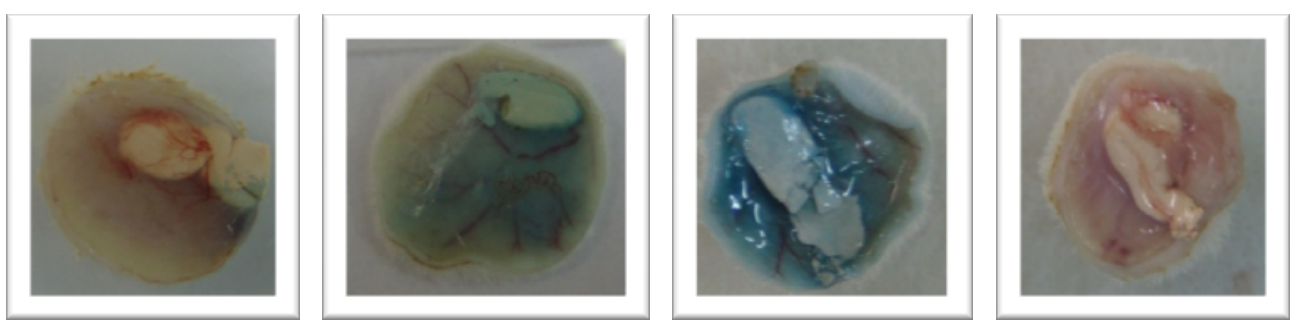

Figura 4.18 - Exemplos de amostras removidas

A seguir, as amostras foram fragmentadas com fragmentador artesanal (Figura 19) e armazenadas em tubos Falcon contendo $5 \mathrm{~mL}$ de formamida (Figuras 4.20 e 4.21 ) em estufa (Fanen - Brasil) a $37^{\circ} \mathrm{C}$ por 48 horas.

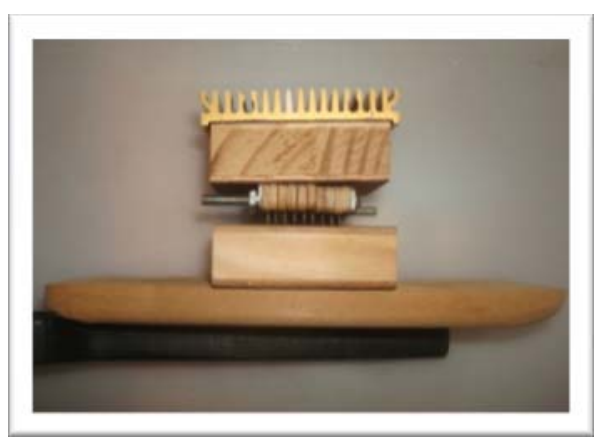

Figura 4.19 - Fragmentador artesanal confeccionado pelo Prof. Dr. Antonio Carlos Bombana 


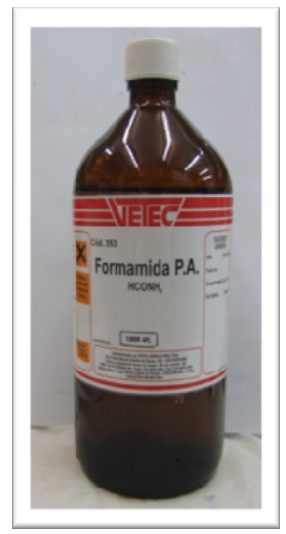

Figura 4.20 - Formamida P.A. utilizada como solvente

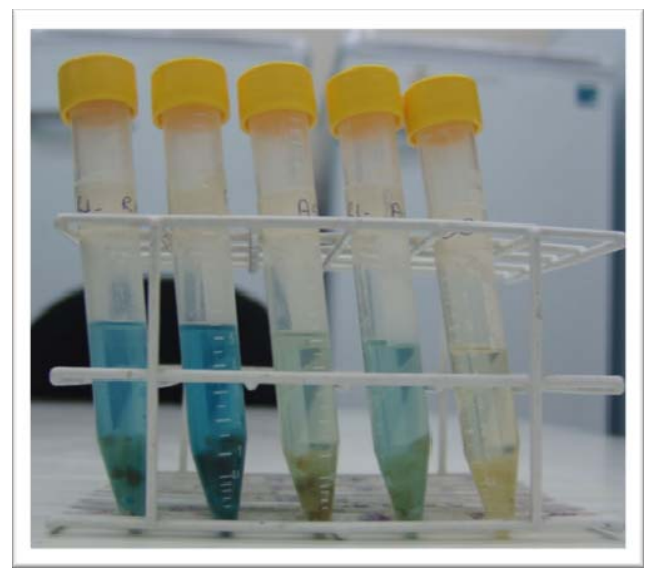

Figura 4.21 - Amostras armazenadas nos tubos Falcon

Decorrido esse tempo, a formamida contendo o corante extraído do tecido era filtrada, centrifugada por 10 minutos a 1500 rpm (Eppendorf) (Figura 4.22).

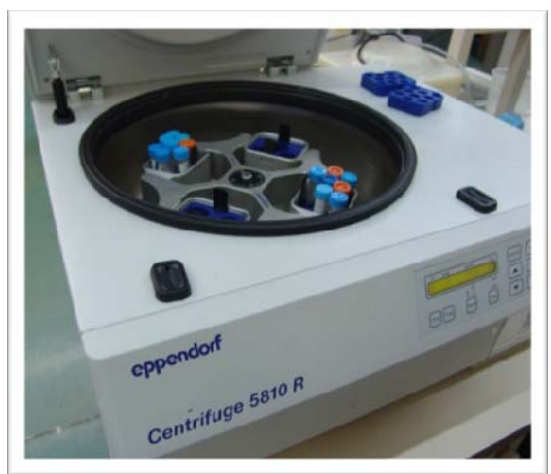

Figura 4.22 - Amostras preparadas para centrifugar 
Para que as leituras fossem realizadas, foi preparada uma concentração padrão do Azul de Evans $(2,5 \mu \mathrm{g})$, assim como um tubo Falcon contendo apenas formamida. A cada leitura, era feita a calibração do espectrofotômetro com a leitura do "branco" (formamida) e também a confirmação da leitura da absorbância da solução padrão.

No momento da construção da tabela de resultados, foram feitas médias dos resultados em absorbância, já que cada substância testada possuía 20 amostras em cada tempo experimental, conforme Anexo C.

A partir dessa média, os resultados foram convertidos em $\mu \mathrm{g}$ de acordo com a fórmula a seguir:

$$
[C] \mu g=\frac{A b S}{A b s(S P)} \quad \times 2,5 \mu g([C] S P)
$$

\section{Onde: [C]= Concentração, Abs=Absorbância e SP=Solução padrão}

A leitura do extravasamento foi feita com $1 \mathrm{~mL}$ da solução no espectrofotômetro (UV Visível- Ultrospec 2000, Pharmacia Biotech, USA.), em 619ワm (pico máximo de absorção do corante) (Figuras 4.23 e 4.24). Os resultados eram anotados na ficha individual de cada animal para serem posteriormente convertidos e tabulados para análise estatística.
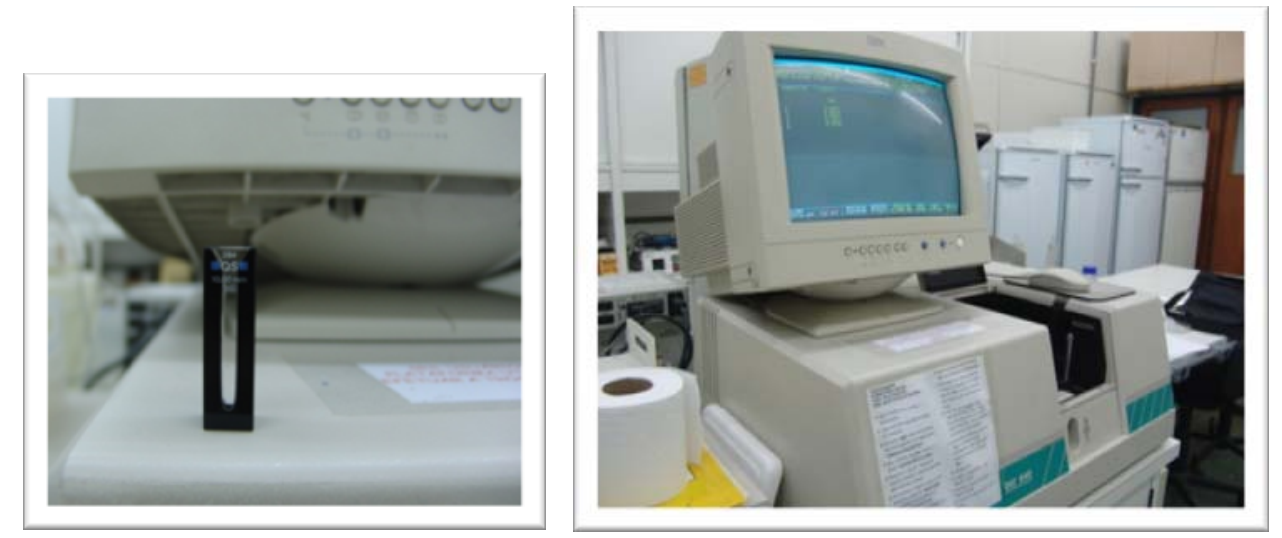

Figuras 4.23 e 4.24 - Tubo para leitura da absorção e espectrofotômetro utilizado 
Neste estudo, cada animal foi seu próprio controle, ou seja, uma área no dorso do rato que não recebeu nenhum material em teste foi removido e processado da mesma maneira que as outras amostras daquele mesmo animal (Figura 4.25). No momento das leituras, o índice obtido no fragmento "controle" era subtraído dos resultados das demais amostras.

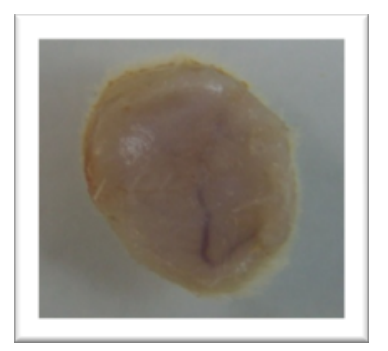

Figura 4.25 - Exemplo da amostra controle

Ao final de toda a fase experimental foram construídas 03 tabelas com todos os resultados obtidos em absorbância, das quais foram feitas as médias para conversão em $\mu g$ e análise estatística (Anexo C). 


\section{RESULTADOS}




\section{RESULTADOS}

A tabela 5.1 e o gráfico 5.1 mostram os resultados das médias de extravasamento do Azul de Evans encontradas, após a conversão dos resultados de absorbância para $\mu \mathrm{g}$.

Tabela 5.1 - Resultados das médias da absorbância em $\mu$ g obtidas

\begin{tabular}{lrrrrr}
$\begin{array}{l}\text { TEMPO I } \\
\text { CIMENTO }\end{array}$ & \multicolumn{1}{c}{ ActiV GP } & \multicolumn{1}{c}{ Biosealer } & \multicolumn{1}{c}{ RealSeal } & \multicolumn{1}{l}{ RoekoSeal } & \multicolumn{1}{c}{ AH Plus } \\
06 horas & 0,6102 & 0,3500 & 0,7919 & 0,2276 & 0,7712 \\
12 horas & 0,6313 & 0,3375 & 0,6448 & 0,2399 & 0,6204 \\
24 horas & 0,4512 & 0,1709 & 0,5379 & 0,1608 & 0,5076 \\
\hline
\end{tabular}

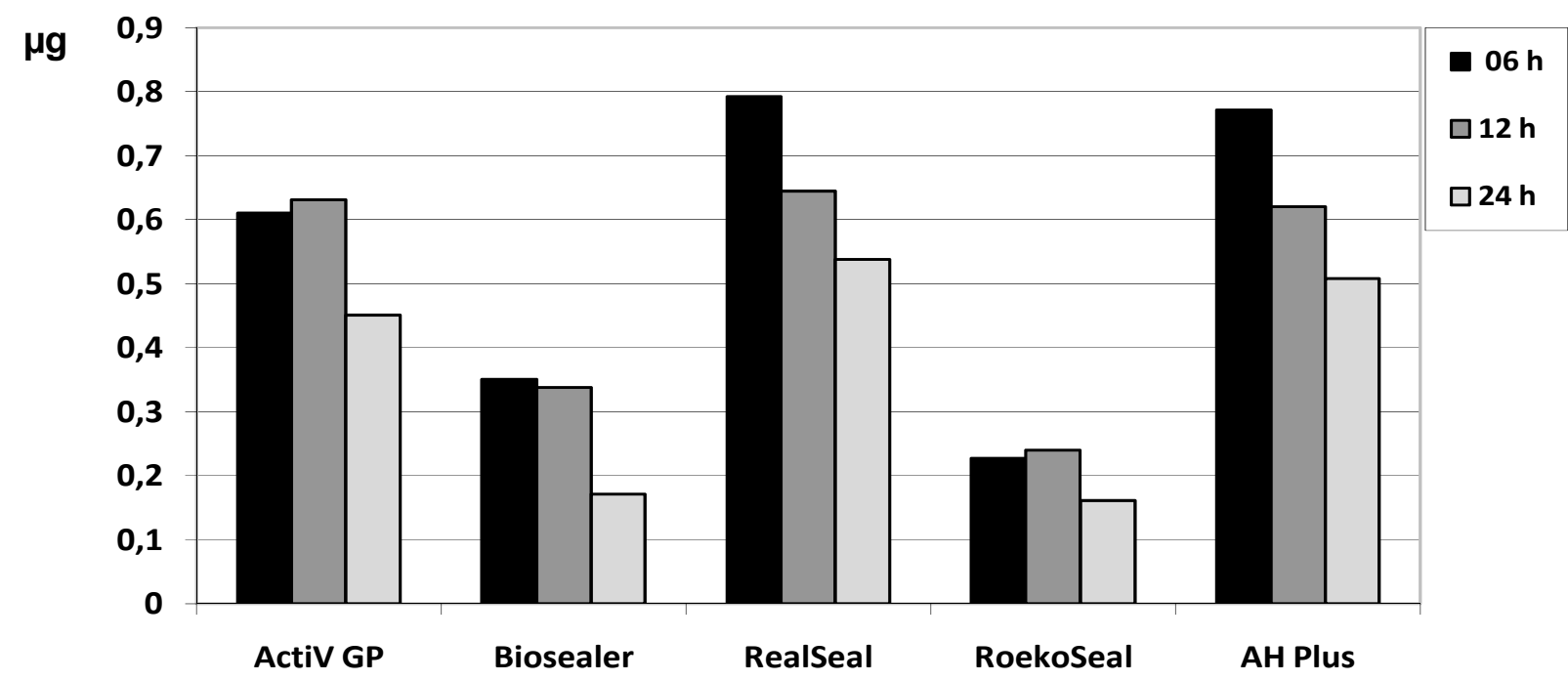

Gráfico 5.1 - Resultados das médias da absorbância em $\mu$ g obtidas

Após os dados obtidos serem submetidos à análise de variância (Tabela 5.2), pôde-se observar que houve diferença estatisticamente significativa entre os materiais, bem como entre os tempos. No entanto, não houve interação entre os fatores em estudo. 
Tabela 5.2 - Análise de Variância (ANOVA)

\begin{tabular}{l|r|r|r|r|r}
\hline $\begin{array}{l}\text { Fonte de variação } \\
\text { (fatores) }\end{array}$ & $\begin{array}{c}\text { Soma dos quadrados } \\
\text { (Tipo III) }\end{array}$ & df & $\begin{array}{c}\text { Quadrado } \\
\text { médio }\end{array}$ & F & valor-p \\
\hline Material & 14,612 & 4 & 3,653 & 78,488 & $<0,0001$ \\
Tempo & 2,530 & 2 & 1,265 & 27,183 & $<0,0001$ \\
Material * Tempo & 0,591 & 8 & 0,074 & 1,587 & 0,128 \\
Error & 13,265 & 285 & 0,047 & & \\
\hline Total & 124,624 & 300 & & & \\
\hline
\end{tabular}

Por ter havido diferença estatisticamente significativa nos resultados obtidos, foi realizado o teste de Tukey $(p<0,05)$. A tabela 5.3 mostra em cada tempo, a significância entre os resultados dos índices de absorbância do Azul de Evans. Em cada tempo, letras iguais $(A, B, C)$ indicam não haver significância estatística e letras diferentes indicam diferenças.

Tabela 5.3 - Teste de Tukey - As letras indicam significância ou não dentro de cada tempo

\begin{tabular}{cccc}
\hline Tempo & Material & Resultado Mean & Teste de Tukey \\
\hline 6 horas & ActiV GP & 0,724900 & A \\
6 horas & Biosealer & 0,415800 & B \\
6 horas & RealSeal & 0,940750 & C \\
6 horas & RoekoSeal & 0,270400 & D \\
6 horas & AH Plus & 0,916200 & C \\
\hline 12 horas & ActiV GP & 0,750000 & A \\
12 horas & Biosealer & 0,401050 & B \\
12 horas & RealSeal & 0,766550 & A \\
12 horas & RoekoSeal & 0,285350 & B \\
12 horas & AH Plus & 0,736550 & A \\
\hline 24 horas & ActiV GP & 0,536250 & A \\
24 horas & Biosealer & 0,202500 & B \\
24 horas & RealSeal & 0,639000 & A \\
24 horas & RoekoSeal & 0,191350 & B \\
24 horas & AH Plus & 0,603050 & A \\
\hline
\end{tabular}


Considerando-se o fator em estudo material, observou-se que o tempo 1 (6 h) demonstrou os maiores índices de extravasamento vascular para cada material testado, quando comparado ao tempo $3(24 \mathrm{~h})$, exceto quando o material RoekoSeal foi testado, onde não houve diferença estatisticamente significativa entre os tempos 1 (6 h), 2 (12 h) e 3 (24 h).

Considerando-se o fator em estudo tempo, observou-se que os materiais ActiV GP, RealSeal e AH Plus obtiveram índices superiores quando comparados aos materiais Biosealer e RoekoSeal, principalmente nos tempos 12 e 24 horas.

Os gráficos a seguir, mostram separadamente por tempo experimental, os dados expressos no quadro acima, com as referidas comparações estatísticas (Gráficos 5.2 a 5.4).

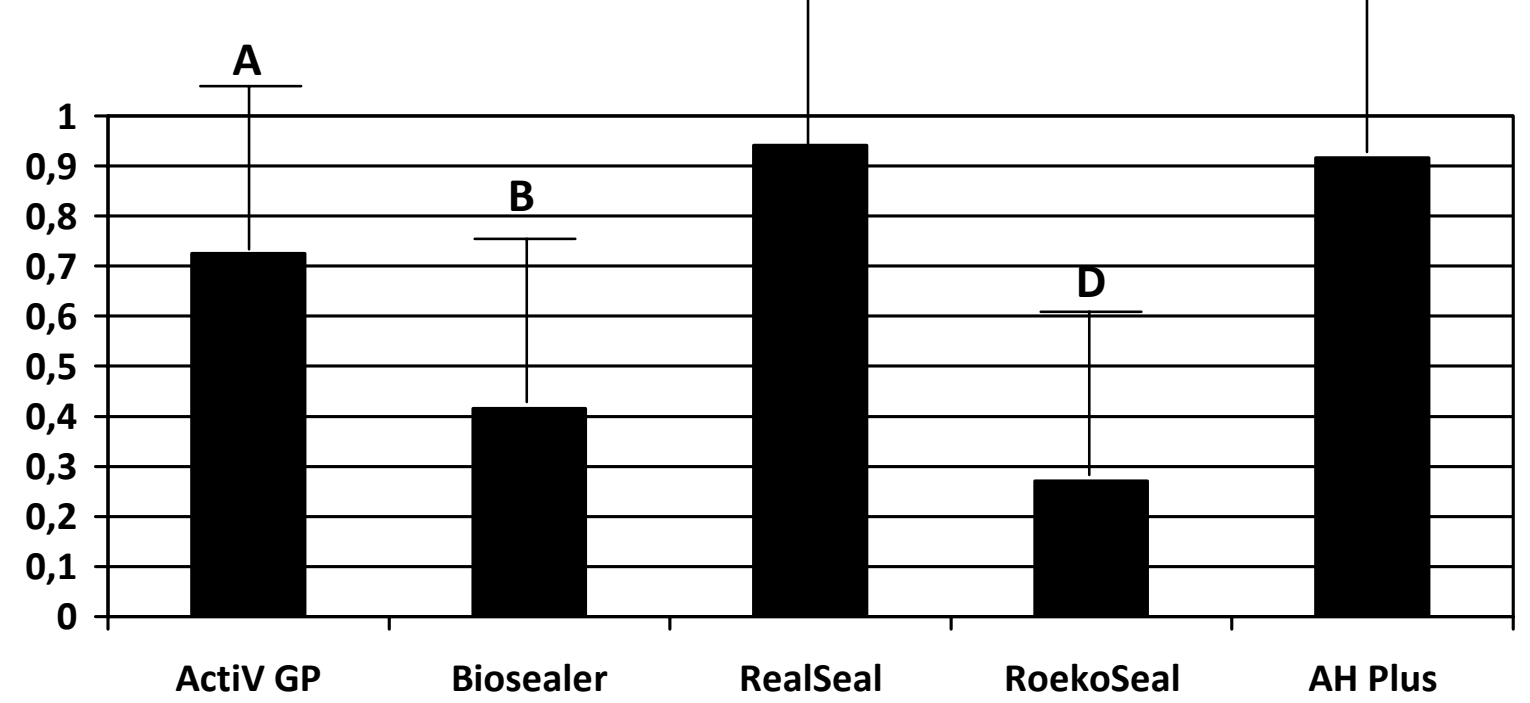

Gráfico 5.2 - Tempo experimental de 6 horas (letras iguais indicam ausência de significância) 


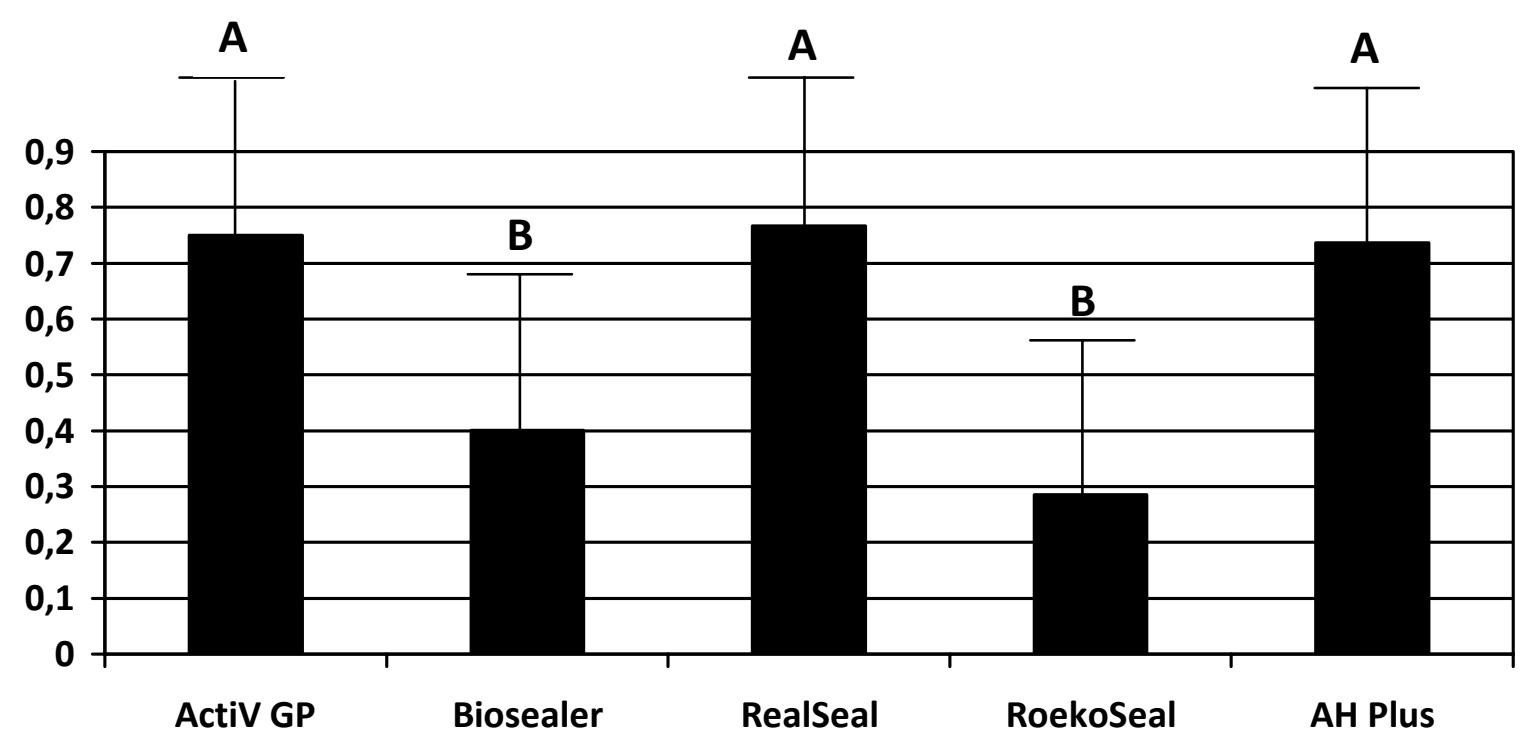

Gráfico 5.3 - Tempo experimental de 12 horas (letras iguais indicam ausência de significância)

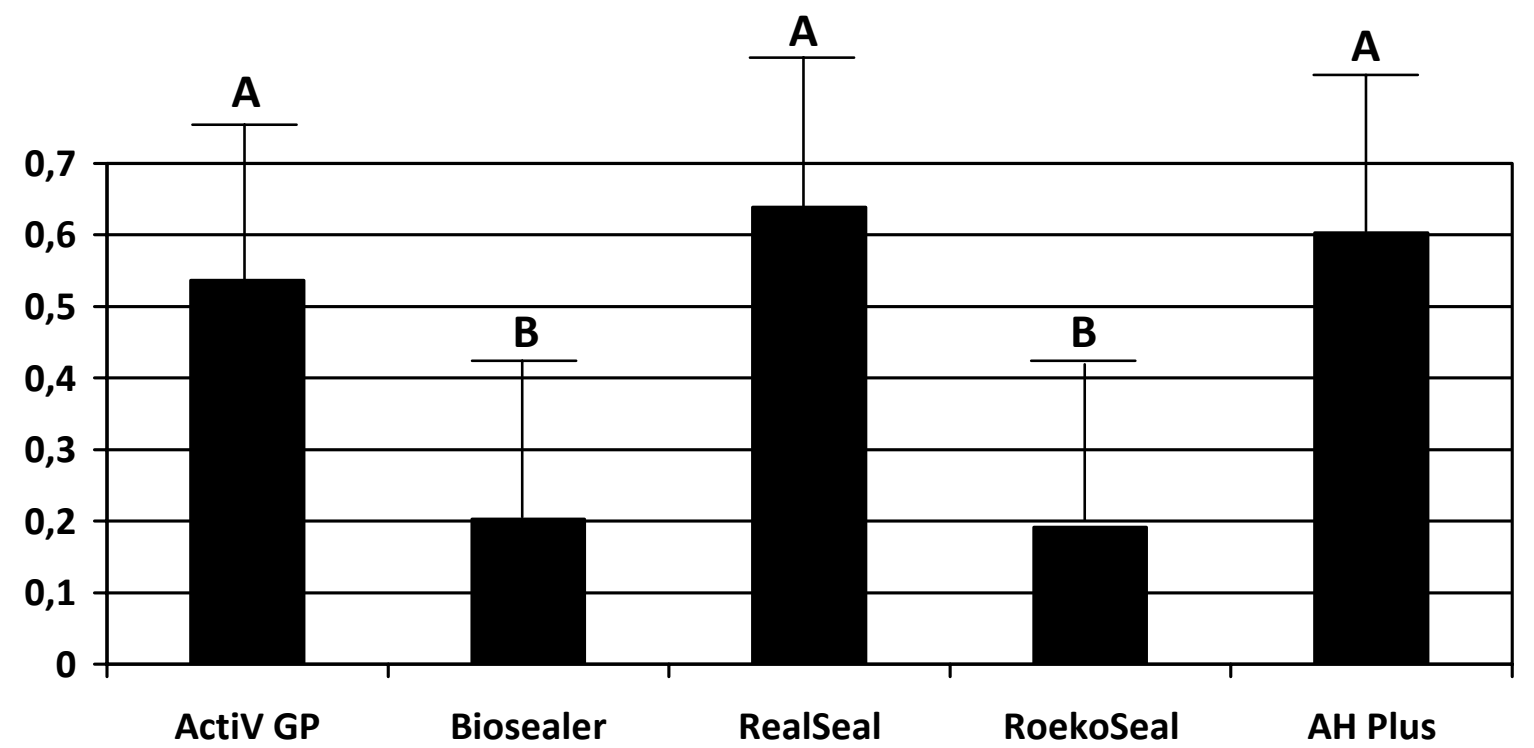

Gráfico 5.4 - Tempo experimental de 24 horas (letras iguais indicam ausência de significância) 
O gráfico a seguir, ilustra o comportamento de cada substância variando-se o tempo (Gráfico 5.5).

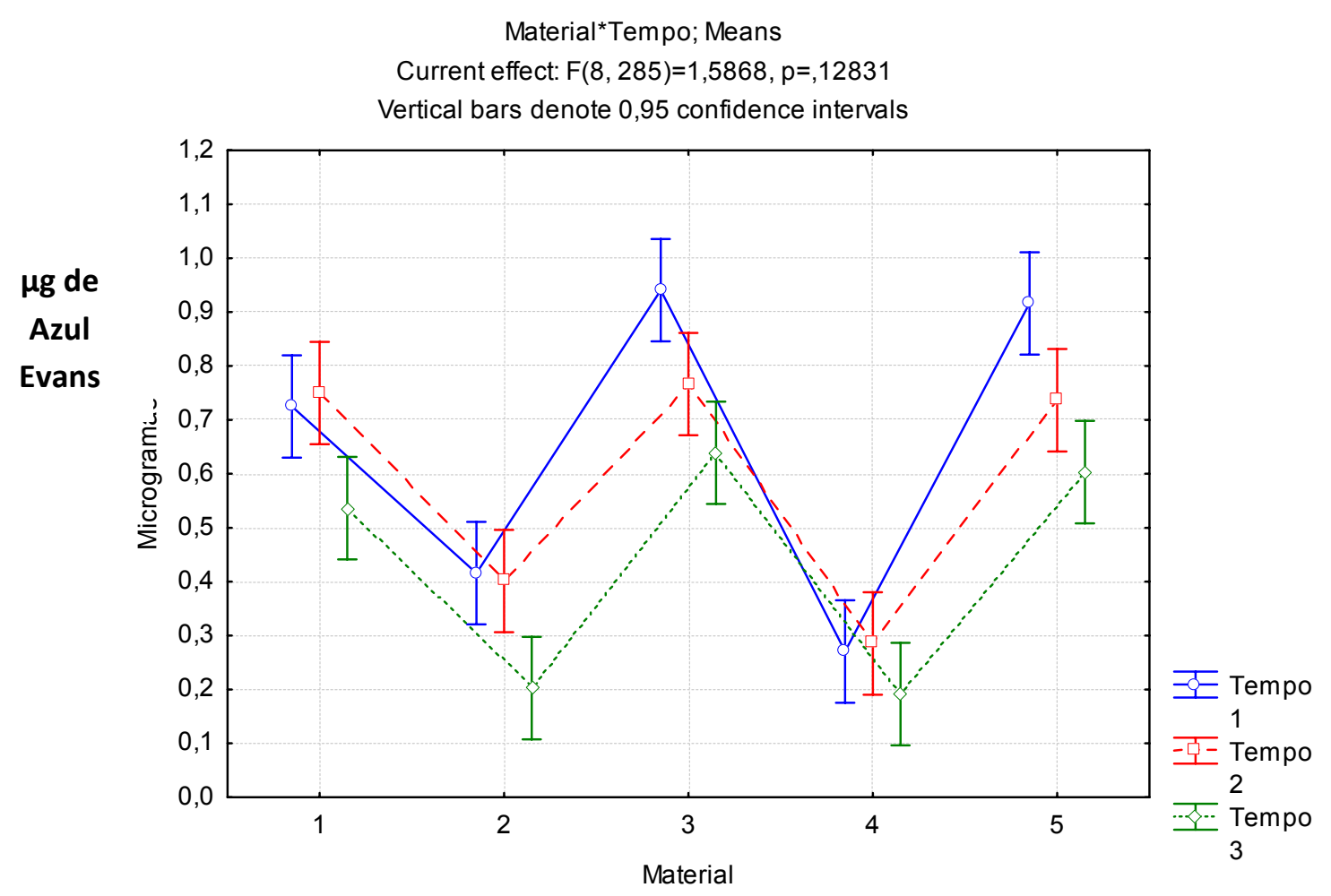

Gráfico 5.5 - Comportamento dos materiais de acordo com o tempo, onde Material 1 é o ActiV GP (G1), 2-Biosealer (G2), 3-RealSeal (G3), 4-RoekoSeal (G4) e 5-AH Plus (G5) e Tempo 1-6 horas, 2-12 horas e 3-24 horas

Dessa maneira, os resultados por grupos após as análises estatísticas apresentaram-se como a seguir:

Tempo experimental de 6 horas: $\mathrm{G} 3 \approx \mathrm{G} 5>\mathrm{G} 1>\mathrm{G} 2>\mathrm{G} 4$

Tempo experimental de 12 e 24 horas. : $\mathrm{G} 1 \approx \mathrm{G} 3 \approx \mathrm{G} 5>\mathrm{G} 2 \approx \mathrm{G} 4$ 


\section{Discussä}




\section{DISCUSSÃO}

\subsection{Do método}

Substância biocompatível é aquela capaz de se unir ou manter-se próxima de outra sem promover trocas químicas degenerativas, sem anular seus efeitos nem sua função (STEDMAN MEDICAL DICTIONARY, 1993). Uma vez que um tecido é exposto a uma substância não compatível com seu metabolismo celular, ele está recebendo uma injúria que pode ser discreta, moderada ou severa.

Diversos autores relataram que, ao promover-se uma reação inflamatória, o aumento do exsudato plasmático para um tecido lesado eleva as taxas de azul de Evans neste tecido (WOODS; SMITH; GRAHAM, 1988; BACCARO; MARIANO; MALUCELLI, 1990; UDAKA; TAKEUCHI; MOVAT, 1970).

Outros corantes, além do azul de Evans, se ligam à albumina, como o azul Celeste de Niágara e o azul Celeste de Pontamina 6BX (UDAKA; TAKEUCHI; MOVAT, 1970; SZABO; PIHAN; TRIER, 1986; WOODS; SMITH; GRAHAM, 1988; BACCARO; MARIANO; MALUCELLI, 1990). Neste estudo, escolhemos o Azul de Evans pelas suas propriedades, como por exemplo, ser um corante capaz de ser mensurável por meio de espectrofotometria (BORDÓN DE CORBALÁN, 1994), e também pela sua ampla aplicabilidade conforme relatado na literatura.

Conforme pudemos confirmar, existem relatos de avaliação do fluxo transcapilar evidenciado através do azul de Evans em diversos tecidos, tais como pele, coração e cólon (BORDÓN DE CORBALÁN, 1994; GREEN, 1988) 
O Azul de Evans é um dos corantes mais indicados para estudos como este por apresentar efeito sistêmico, baixa toxicidade ao organismo e ainda, a propriedade de ligar-se à albumina plasmática, a qual é um dos indicativos de formação de edema durante a resposta inflamatória (BELAYEV, 1996). Além disso, indica formação de edema através de espectrofotometria (MEDEIROS, 1995).

Estudos utilizando o Azul de Evans para quantificar edemas também foram aplicados por Lindsberg, Siren e Hallenbeck (1997), que causaram edemas em cérebros de ratos com laser de Nd:YAG e os quantificaram por microscopia de fluorescência a laser e Taherzadeh e Warren (1997), que causaram edemas em pele escrotal de ratos com Diltiazem e mensuraram o fluxo de sangue com laser Doppler, quantificando o edema através da técnica da albumina marcada com $125 \mathrm{I}$.

Outro método de análise edemogênica empregada por meio do extravasamento do Azul de Evans em processos inflamatórios imediatos foi empregado por Melo, em 2002, quando da indução por carragenina em ratos que foram analisados num espectrofluorímetro. O estudo, que não exige o sacrifício das cobaias, foi comparado com o método clássico do teste edemogênico e foi possível concluir que os dois métodos permitem avaliar, qualitativa e quantitativamente o grau de inflamação dos tecidos. Vale analisar que o não sacrifício das cobaias está relacionado à leitura feita em comprimento de onda de $458 \mathrm{~nm}$, metodologia interessante, mas com aparato ainda pouco aplicado em Endodontia.

Poucos estudos utilizando o método do Azul de Evans para avaliar a biocompatibilidade de cimentos endodônticos foram publicados, dentre ele está de Canova et al. (2002) que avaliaram a biocompatibilidade tecidual dos cimentos Endométhasone, Sealapex, Sealer Plus e Sealer 26. Nenhuma dessas substâncias foi estudada em nossa pesquisa, no entanto, corroboram com seus resultados ao 
afirmar que em todos os nossos resultados, também o maior índice de exsudato inflamatório foi no menor período de tempo (03 horas).

A utilização das perfurações centrais permitiu evitar que aquelas regiões, agredidas pela estivessem próximas a área de inserção dos cimentos e assim, procedeu-se a utilização de um cateter como forma de não utilizar pérfuro-cortantes no trajeto que seria realizado pelo material. A obtenção do tecido ao redor do cimento foi padronizada pelo uso do vazador de ferro de $15 \mathrm{~mm}$ de diâmetro, evitando variações no tamanho da peça, resultando em alterações na quantidade de corante extravasado, interferindo no resultado final.

\subsection{Das substâncias}

$\mathrm{Na}$ inflamação, a vasodilatação e o aumento da permeabilidade vascular na microcirculação conduzem a uma taxa acelerada de passagem de proteínas plasmáticas na direção do tecido extravascular, definida como exsudação. Este fenômeno conduz ao edema (UDAKA; TAKEUCHI; MOVAT, 1970), que é importante na limitação e contenção da agressão, pois dilui o agente agressor, facilita a sua retirada do local e traz para o interstício imunoglobulinas, complemento e outras macromoléculas envolvidas na inibição ou mesmo destruição de certos agressores, assim como na modulação da própria resposta inflamatória (MONTENEGRO; FECCHIO, 1992). 
A escolha dos cimentos a serem testados se deu com base na classificação de seu principal componente em: à base de resinas, à base de silicones, à base de ionômero de vidro e à base de óleo de copaíba.

Especificamente para a Endodontia, a idéia da utilização dos cimentos à base de ionômero de vidro ao invés dos cimentos resinosos, conforme afirmaram Koch e Brave (2006) advêm do fato da busca de algo que suprisse as dúvidas com relação aos cimentos resinosos, quanto à presença dos produtos do hipoclorito de sódio nos canais radiculares dificultando sua polimerização.

O ActiV GP, foi o primeiro cimento com base ionomérica a ser lançado desde o Ketac Endo, o qual havia sido diversas vezes rejeitado devido a sua pouca capacidade adesiva. Tal propriedades foram positivamente afirmadas por Fisher, Berzins e Bahcall, em 2007, com relação ao ActiV GP.

Neste estudo, o cimento com base de ionômero de vidro, mostrou-se homogêneo e regular em todos os tempos experimentais, mesmo tendo um comportamento inferior ao RoekoSeal e ao Biosealer.

Tendo em vista, que os cimentos ionoméricos são amplamente aplicados na Dentística Restauradora e Odontopediatria, esperava-se desse cimento bons resultados de biocompatibilidade, no entanto, trata-se de material novo, que ainda carece de estudos científicos que comprovem sua eficácia.

Durante os experimentos, foi possível observar uma intensa expansão deste material desde o primeiro tempo experimental, apesar de não termos observado atividade inflamatória intensa, pode-se afirmar que nas 20 amostras o ActiV GP apresentou expansão visível a olho nu, depois de tomar presa junto ao tecido subcutâneo dos ratos. 
Outra substância que pode ser uma alternativa para o tratamento endodôntico e largamente estudada no momento é a copaíba, conforme afirmaram Silva, Almeida e Sousa (2004), são produtos naturais que podem ser uma alternativa no tratamento endodôntico.

Os óleos de copaíba estudados por Veiga Jr. et al. (2001) eram todos conseguidos facilmente em supermercados da região amazônica. Os autores comentaram que a copaíba realmente tem ação antiinflamatória, mas que é necessária a padronização do preparo por conta das adulterações existentes.

Assim, como aconteceu com os estudos acerca dos cimentos à base de ionômero de vidro, pelos mesmos motivos iniciaram-se as pesquisas para formulação de um cimento brasileiro, com propriedades próximas àquelas consideradas ideais. Em 2006, foi publicado o estudo de Garrido et al., sobre a biocompatibilidade de um cimento experimental à base de um fitoterápico amazônico, óleo-resina de copaíba.

Na ocasião, o cimento foi chamado de Cop Endo, mais tarde distribuído como Biosealer e que ainda está de processo de aprovação do nome pelo fabricante.

Durante os experimentos, notou-se rápido tempo de presa deste material, mesmo no ambiente úmido (tecido), e por meio dos resultados obtidos, observou-se que por ter apresentado irritabilidade moderada nos dois primeiros tempos experimentais e discreta no último, é possível acreditar, como em outros estudos que os cimentos com base de fitoterápicos, especialmente a copaíba, podem ser uma boa alternativa para a obturação endodôntica.

Os cimentos à base de silicone também são novidades nas últimas décadas e foram lançados também observando a nova gama de materiais obturadores como alternativas aos tradicionais cimentos com base em óxido de zinco e eugenol, 
conforme afirmaram Bouillaguet et al. (2004, 2006), Lodiene et al. (2007) e Schwarze, Leyhausen e Geurtsen (2002).

Na presente pesquisa, o RoekoSeal, mostrou o mais homogêneo e regular dentre os materiais testados e além disso, sua atividade foi considerada discreta do ponto de vista do índice de absorbância do Azul de Evans. Na fase experimental, ele foi o material que apresentava também clinicamente, situações de aparente "inocuidade" junto ao tecido.

Os cimentos resinosos empregados neste trabalho, são certamente mais amplamente estudados que os demais e àqueles que estão a mais tempo no mercado, apesar de fazerem parte da nova geração de cimentos endodônticos. São eles o RealSeal, (base de resina de metacrilato) e o AH Plus (base de resina epóxica).

Com relação ao $\mathrm{AH}$ Plus, ele já vem de uma evolução de um cimento chamado AH 26 do qual foi retirado da sua composição a hexametilenotetramina, o que transformaria o $\mathrm{AH}$ Plus em um cimento livre de formaldeído. Segundo o fabricante, ele usa outro tipo de amina e uma reação de presa baseada na reação térmica adicional epóxica-amina (KOULAOUZIDOU et al., 1998), apesar disso, baixos níveis de liberação de formaldeído, também puderam ser constatados com o AH Plus, provavelmente devido à reação da resina epóxica com as aminas para iniciar a presa do cimento (COHEN et al., 2000), nos experimentos desenvolvidos em cultura de células. Isto poderia explicar porque o $\mathrm{AH}$ Plus que apresenta liberação mínima de formaldeído, mas contém resina epóxica, ainda apresenta toxicidade (COHEN et al., 2000; JUKIĆ et al., 2000).

Ainda que sejam nos dias de hoje os mais utilizados em todo o mundo, observou-se que os cimentos resinosos, quando em contato com o tecido do rato, 
mostraram-se severamente irritantes durante os experimentos, apesar de inúmeros estudos de biocompatibilidade acerca deles, (MERDAD, 2007; MILETIC, 2005; ONAY, 2007, SCHWARZE, 2002) foi possível observar clinicamente e também nos resultados que seu comportamento não foi bem tolerado pelos animais, quando da aplicação desta metodologia e destes tempos experimentais.

\subsection{Dos resultados}

É possível começar a discussão dos nossos resultados retomando os trabalhos de Nagem-Pereira e Pereira (1976), que determinaram um índice de severidade de acordo com o nível de absorbância em testes edemogênicos até hoje aplicado. De acordo com aquelas observações nossos resultados seriam assim classificados (Quadro 6.1):

\begin{tabular}{|l|l|l|l|l|l|}
\hline 6 horas & ActiV GP & Biosealer & RealSeal & RoekoSeal & AH Plus \\
\hline & Severo (B) & Moderado (C) & Severo (A) & Discreto (D) & Severo (A) \\
\hline $\mathbf{1 2}$ horas & ActiV GP & Biosealer & RealSeal & RoekoSeal & AH Plus \\
\hline & Severo (A) & Moderado (B) & Severo (A) & Discreto (B) & Severo (A) \\
\hline 24 horas & ActiV GP & Biosealer & RealSeal & RoekoSeal & AH Plus \\
\hline & Moderado (A) & Discreto (B) & Severo (A) & Discreto (B) & Moderado (A) \\
\hline
\end{tabular}

Quadro 6.1 - Comparação dos resultados desta pesquisa à classificação de NagemPereira e Pereira (1976) - letras iguais indicam ausência de significância

Esses resultados vão de encontro à análise estatística deste estudo que explica não haver relação entre os tempos, mas sim entre os materiais, exceto no material com base de silicone, RoekoSeal. Ou seja, o comportamento dos materiais diminuiu a irritabilidade apenas no terceiro tempo experimental. 
Dados estes que discordam dos resultados de Bouillaguet et al. (2006) que pesquisaram a citotoxidade de discos dos cimentos AH Plus, Epiphany e GuttaFlow em contato com culturas de células. Os resultados mostraram que todos os materiais têm poder citotóxico e que este aumenta conforme o tempo.

Para diversos autores, os cimentos com base em silicone, mostraram-se menos citotóxicos quando comparados aos cimentos de outras bases. (LODIENE et al.; ELDENIZ et al., 2007; SCHWARZE, LEYHAUSEN; GEURTSEN, 2002).

Como foi possível observar, a metodologia pareceu bem aplicada quando comparados aos estudos mais amplos acerca de tal metodologia, muitos deles aplicados em Endodontia com substâncias químicas irrigadoras (BIANCONCINI, 2001; TRUJILLO JUNIOR et al., 2003) e na área médica, seja, oftalmologia, ortopedia ou outras áreas (BACCARO; MARIANO; MALUCELLI, 1992; GEHLEN et al., 2004).

Observa-se também que nenhum dos materiais apresentou comportamento severo no período de 24 horas, sendo possível afirmar que todos eles, têm o seu potencial irritativo diminuído com o passar do tempo, o que traduz a idéia do estudo da resposta inflamatória tardia dos mesmos materiais, para acompanharmos o processo reparacional dos tecidos depois da agressão.

Além disso, o método mostra-se mais simples de ser aplicado que os testes histológicos comumente utilizados para estudar respostas inflamatórias. Para melhorar tais análises, pode-se sugerir a aplicação de testes Elisa para estudo dos mediadores químicos (citocinas) envolvidas no processo inflamatório. 
cONCLUSÖES 


\section{CONCLUSÕES}

A análise e discussão dos resultados obtidos no presente trabalho permitiram-nos concluir que:

1 - O cimento RoekoSeal demonstrou o menor grau de irritabilidade no tempo experimental de 6 horas.

2 - Os cimentos RealSeal e AH Plus apresentaram resposta inflamatória mais intensa no período experimental de 6 horas.

3 - O índice de irritabilidade nas primeiras 6 horas é significativamente superior quando comparado ao período de $24 \mathrm{~h}$, independente do material testado. 


\section{REFERANCIAS}




\section{REFERÊNCIAS ${ }^{1}$}

Alle N. Estudo das propriedades antiinflamatórias e antimitótica das drogas: Indometacina, Butazona, Clinoril, Naprosin, Benflogin e Inflaril. Análise comparativa em ratos [Tese Livre-Docência]. Bauru: Faculdade de Odontologia de Bauru da USP; 1985.

Baccaro MR, Mariano M, Malucelli BE. Chronically inflammed tissue activates plasma mediators of vascular permeability [published erratum in Braz J Med Biol Res 1990;23:477]. Braz J Med Biol Res 1990;23:179-85.

Becker PFL. Patologia Geral. São Paulo: Sarvier; 1997

Belayev L. Quantitative evaluation of blood-brain barrier permeability following middle cerebral artery occlusion in rats. Brain Res 1996;739 88-96.

Bianconcini, IV. Avaliação da citotoxidade do digluconato de clorexidina a $2,5 \%$ e a $5 \%$, do hipoclorito de sódio a $1 \%$ e do soro fisiológico, em subcutâneo de ratos [Dissertação Mestrado]. São Paulo: Faculdade de Odontologia da USP; 2001.

Biocompatibility. In: STEDMAN, T.L. Stedman’ Medical Dictionary. Baltimore, Willians \& Wilkins, 1989.

Bombana AC. Estudo comparativo da reação tecidual conjuntiva do subcutâneo de ratos, frente a inserção de tubos de polietileno preenchidos com cimento N-Rickert com e sem extravasamento: contribuição ao estudo [Dissertação de Mestrado]. São Paulo: Faculdade de Odontologia da USP; 1981.

Bordón de Corbalán AC. Aplicação do micrométodo espectrofotométrico para a determinação de azul de Evans em plasma e tecido colônico de ratos Wistar [Dissertação de Mestrado] Curitiba: Universidade Federal do Paraná; 1994. 
Bouillaguet S, Wataha JC, Lockwood PE, Galgano C, Golay A, Krejci I. Citotoxicity and sealing properties of four classes of endodontic sealers evaluated by succinic dehydrogenase activity and confocal laser scanning microscopy. Eur J Oral Sci 2004;112(2):182-7.

Bouillaguet S, Wataha JC, Tay FR, Brackett MG, Lockwood PE. Initial in vitro biological response to contemporary endodontic sealers. J Endod 2006;32(10):98992.

Brancaleon L. In vivo fluorescence spectroscopy of nonmelanoma skin cancer. Photochem Photobiol 2001; 73(2)178-83.

Brito NMB, Kulay-Junior L, Simões MJ, Lameira OA, Lamarão LG, Damous SHB. Aspectos morfológicos e morfométricos do colo uterino de ratas ooforectomizadas após aplicação de óleo de copaíba. Rev Bras Ginecol Obstet 2000:22(8):489-93.

Brunini SHS. Avaliaçäo da intensidade da reaçäo do tecido conjuntivo subcutâneo de ratos frente ao implante dos cimentos endodônticos endométhasone, Sealer $26 \mathrm{e} \mathrm{AH}$ Plus: teste edemogênico e análise microscópica [Dissertação de Mestrado]. Bauru: Faculdade de Odontologia de Bauru da USP; 2001.

Bunczak-Reeh MA, Hargreaves KM Effect of inflammation on the delivery of drugs to dental pulp. J Endod 1998:24(12):822-5.

Canova GC, Taveira LAA, Dezan-Junior E, Nishiyama CK, Spalding M. Estudo do poder flogógeno de quatro cimentos obturadores de canais radiculares por meio do teste edemogênico. Rev Fac Odontol Bauru 2002;10(3):128-33.

Cantazaro-Guimarães SA. Patologia basica da cavidade bucal. Rio de Janeiro: Guanabara Koogan; 1982.

Cantazaro-Guimarães SA, Akatsu T, Taga E, Consolaro A. Assessment of the antiexudative and antiproliferative activities of non-steroidal anti-inflammatory drugs in inflammatory models developed in rats by subcutaneous implantation of bacterial cell walls from the dental plaque. Inflammation 1996;20(6) 623-36. 
Caster WO, Simon AB, Armstrong WD. Evans blue in tissues of the rat. Am J Physiol 1955;183:317-21.

Clausen DF, Lifson N. Determinations of Evans blue dye in blood and tissues. Proc Soc Exp Biol Med 1956;91:11-4.

Cohen BI, Pagnillo MK, Musikant BL, Deutsch AS. An in vitro study of the cytotoxicity of two root canal sealers. J Endod 2000;26(4): 228-9.

Consolaro A. Estudo do efeito antiinflamatório da talidomida [Tese Livre-Docência]. Bauru: Faculdade de Odontologia de Bauru da USP; 1991.

Correa P, Arias-Stella J, Tamayo RP. Texto de patología. México La Prensa Médica Mexicana; 1970.

Cotran RM, Kumar V, Robbins SL. Robbins: pathologic basis of disease. Philadelphia : Saunders; 1994.

Cotran RS. Patologia estrutural e funcional. Rio de Janeiro: Guanabara Koogan; 1996.

Cotran RS, Kumar V, Collins T. Patologia estrutural e funcional. Rio de Janeiro: Guanabara Koogan; 2000.

Eldeniz AU, Mustafa K, Ørstavik D, Dahl JE. Cytotoxicity of new resin-, calcium hydroxide- and silicone-based root canal sealers on fibroblasts derived from human gingiva and L929 cell lines. Int Endod J 2007;40(5):329-37.

Fantone E, Peter JC, Ward A. Inflamação. In: Rubin E, Farber JL. Patologia. Rio de Janeiro: Interlivros; 1990:32-57.

Fisher MA, Berzins DW, Bahcall JK. An in vitro comparison of bond strength of various obturation materials to root canal dentin using a push-out test design. $\mathrm{J}$ Endod 2007;33(7):856-8. 
Freedman FB, Johnson J. Equilibrium and kinetic properties of the Evans bluealbumin system. Am J Physiol 1969;16:675-81.

Garcia-Leme J, Shapoval EES. Stimulation of the hypothalamic-pituitaryadrenal axis by compounds formed in inflamed tissue. Braz J Pharm Sci 1975; 53:75-83.

Garrido ADB, Lia RCC, Bombana AC*, Sousa-Neto MD, França SC, Silva JF, AstolfiFilho S. Reações teciduais apicais frente à obturação de canais radiculares de cães com diferentes cimentos endodônticos Braz Oral Res 2006:20:216.

Gehlen ML, Moreira H, Moreira L, Sabag FP, Repka JCD. Spectrophotometric evaluation of Evans blue in inflammatory cornea reaction: experimental study in rabbits. Arq Bras Oftalmol 2004;67:219-25.

Green TP, Johson DE, Marchessault RP, Gatto CW. Transvascular flux and tissue accrual of Evans blue: effects of endotoxin and histamine. J Lab Clin Med 1988;11:173-83.

Guimarães SA, Akatsu T, Tago EM, Consolaro A. Assessment of the antiexudative and antiproliferative activities of non-steroidal anti-inflammatory drugs in inflammatory models developed in rats by subcutaneous implantation of bacterial cell walls from the dental plaque. Inflammation 1996;20(6):623-36.

Guyton AC. Tratado de fisiologia médica, 5.ed., Rio de Janeiro, Interamericana: 1976.

Guyton AC, Hall JE. Fisiologia humana e mecanismos das doenças. Rio de Janeiro: Guanabara Koogan; 1998.

Jönsson A.Quantification of burn induced extravasation of Evan's blue albumin based on digital image analysis. Computers 1998;28:153-67.

Jukić S, Miletić I, Anić I, Britvić S, Osmak M, Sistig S.The mutagenic potential of AH+ and AH26 by Salmonella/microsome assay. J Endod. 2000 Jun;26(6):321-4. 
Kerezoudis NP, Olgart L, Edwall L. Evans blue extravasation in rat dental pulp and oral tissues induced by electrical stimulation of the inferior alveolar nerve. Arch of Oral Biol 1993;38(10):893-901.

Key JE, Rahemtulla FG, Eleazer PD. Cytotoxicity of a new root canal filling material on human gingival fibroblasts. J Endod 2006;32(8):756-8.

Koch K, Brave D. A new endodontic obturation technique. Dent Today 2006 May;25(5):102-104-7.

Kolokuris I, Beltes P, Economides N, Vlemmas I. Experimental study of the biocompatibility of a new glass-ionomer root canal sealer (Ketac-Endo). J Endod 1996;22(8):395-8.

Konjetzny GE. Die entzundung des magens. In: Handz S. Pathologyc anathomy. Berlin: Springer-Verlag; 1928:4:768.

Koulaouzidou EA, Papazisis KT, Beletes P, Geromichalos GD, Korsaris AH. Cytotoxicity of three resin-based root canal sealers: an in vitro evaluation. Endod Dent Traumatol 1998;14(4):182-5.

Leveen $\mathrm{HH}$, Fishman $\mathrm{WH}$. Combination of Evans blue with plasma protein: its significance in capillary permeability studies, blood dye disappereance curves, and its use as a protein tag. Am J Physiol 1947;26:26-33.

Lewis GP. Mediators of inflammation. Bristol: Wright; 1986.

Leyhausen G, Heil J, Reifferscheid G; Waldmann P, Geurtsen W. Genotoxicity and cytotoxicity of the epoxy resin-based root canal sealer AH plus. J Endod 1999;25(2):109-13.

Linderkamp O, Mader T, Butenandt O, Riegel KP. Plasma volume estimation in severely ill infants and children using a simplified Evans blue method. Eur J Pediatr 1977;125:135-41. 
Lindsberg PJ, Siren AL, Hallenbeck JM. Microvascular perfusion during focal vasogenic brain edema: A scanning laser fluorescence microscopy study. Microvasc Res 1997;53:92-103.

Lodiene G, Morisbak E, Bruzell E, Orstavik D. Toxicity evaluation of root canal sealers in vitro. Int Endod J 2007;41(1):72-7.

Medeiros MVI. Effect of cronic nitric synthesis inhibition on the inflammatory responses induced by carrageenin in rats. Europ J Pharmacol. 1995;(285):109-14.

Melo MS. Análise da dinâmica de edemas agudos em pele de ratos utilizando espectroscopia de fluorescência. [Dissertação de Mestrado] São Paulo: Instituto de Pesquisa e Desenvolvimento da Engenharia Biomédica UNIVALE; 2002.

Merdad K, Pascon AE, Kulkarni G, Santerre P, Friedman S. Short-term cytotoxicity assessment of components of the epiphany resin-percha obturating system by indirect and direct contact millipore filter assays. J Endod 2007;33(1):24-7.

Miletic I, Devcic N, Anic I, Borcic J, Karlovic Z, Osmak M. The Cytotoxicity of RoekoSeal and AH Plus Compared during Different Setting Periods. J Endod 2005: 31(4):307-9.

Montenegro MR, Fecchio D. Inflamação: conceitos gerais e inflamação aguda. In: Montenegro MR, Franco M. Patologia: processos gerais. São Paulo: Atheneu; 1992. p. 99-117.

Monticelli F, Sword J, Martin RL, Schuster GS, Weller, RN, Ferrari M, et al.. Sealing properties of two contemporary single-cone obturation systems. Int Endod $\mathrm{J}$ 2007:40(5):374-85.

Motta MESFM. Efeito de alguns cimentos cirúrgicos (Gengipac com eugenol, Gengipac sem eugenol) e de um condicionador de tecidos (FITT) na exsudação plasmática e na composição celular de granulomas de alta renovação [Dissertação de Mestrado]. Bauru: Faculdade de Odontologia de Bauru da USP 1982. 
Nagem-Filho H, Pereira JC. Evaluation of the irritative potential of some intra canal medicaments in the exudative phase of inflamatory process. Estomatol Cult 1976:;0(1):1-6.

Nassri MRG, Lia RCC, Bombana AC Analysis of the tissue answer regarding two root canal sealers. Appl Oral Sci 2003;11(1):9-14.

Onay $\mathrm{EO}$, Ungor M, Ozdemir BH. In vivo evaluation of the biocompatibility of a new resin-based obturation system. Oral Surg, Oral Medic, Oral Pathol, Oral Radiol, \& Endodon. 2007;104(3):60-6.

Pasternak Júnior B, Tavares D, Perin FM. Avaliação da biocompatibilidade de soluções de hipoclorito de sódio, clorexidina e uma combinação destas. Jornal Bras de Endo/Perio 2002;3(10):233-6.

Pereira FEL, Bogliolo L. Patologia geral. Rio de Janeiro: Guanabara Koogan; 1998.

Perez-Tamayo R. Introducíon a la patología. Buenos Aires: Médica Panamericana; 1986.

Rawson RA. The binding of T-1824 and structurally related diazo dyes by the plasma proteins. Am J Physiol 1943:138:708-17.

Ribeiro GG. Avaliação da reação do tecido subcutâneo de ratos ao digluconato de clorexidina a $2 \%$ e à pasta de hidróxido de cálcio. Análises edemogênico e microscópica óptica [Dissertação de Mestrado]. Bauru: Faculdade de Odontologia de Bauru da USP; 2002

Robins SL, Cotran RS, Kumar V. Pathologic basis of disease. Philadelphia. W.B. Saunders Co; 1984.

Rocha e Silva M, Garcia-Leme J. Chemical mediators of the acute inflammatory reaction. Oxford : Pergram; 1972.

Rutberg M, Spangberg E, Spangberg L. Evaluation of enhanced vascular permeability of endodontic medicaments in vivo. J Endod 1977;3(9):347-51. 
Santa Cecilia M. Propriedades físico-químicas e biológicas de uma solução irrigadora experimental [Tese de Doutorado]. Bauru: Faculdade de Odontologia de Bauru da USP; 1999.

Schwarze T, Leyhausen G, Geurtsen W. Long-term cytocompatibility of various endodontic sealers using a new root canal model. J Endod 2002;28(11):749-53.

Silva FB, Almeida JM, Sousa SMG. Natural medicaments in endodontics - a comparative study of the anti-inflammatory action. Braz Oral Res 2004;18(2): 174-9.

Sousa CJ, Montes CR, Pascon EA, Loyola AM, Versiani MA. Comparison of the intraosseous biocompatibility of AH Plus, EndoREZ, and Epiphany root canal sealers. J Endod. 2006:32(7):656-62.

Sousa SMG. Avaliação da biocompatibilidade do EDTA, EGTA e ácido cítrico pela técnica de exudação de corantes vitais [Tese de Doutorado]. Bauru: Faculdade de Odontologia de Bauru da USP; 1999.

Souza CAM, Cunha FQ, Ferreira, SH. Inflammatory edema and migration of leucocytes but not phagocytosis are reduced in young rats. Med and Biol Res 1994:27:663-70.

Staveren HJ. Fluorescence imaging and spectroscopy of ethil nile blue A in animal models of (pre) malignancies. Photochem Photobiol 2001;73(1):32-8.

Steele $\mathrm{RH}$, Wilhelm DL. The inflammatory reaction in chemical injury. Increased vascular permeability and erythema induced by various chemicals. Br J Exp Pathol 1966;47:612-23.

Susini G, About I, Tran-Hung L, Camps J. Cytotoxicity of epiphany and resilon with a root model. Int Endod J 2006;39(12):940-4.

Swingle KF, Shideman FE. Phases of the inflammatory response to subcutaneous implantation of a cotton pellet and their modifications by certain anti-inflammatory agents. J Pharmacol, Exp Ther 1972;183(1):226-33. 
Szabo S, Pihan G, Trier JS. Alterations in blood vessels during gastric injury and protection. Scand J Gastroenterol 1986;21(Suppl 125):92-9.

Taherzadeh M, Warren JB. Comparison of diltiazem and verapamil on rat microvascular permeability. Microvasc Res 1997;54:206-13.

Tanomaru-Filho M, Jorge EG, Tanomaru JMG, Gonçalves M. Evaluation of the radiopacity of calcium hydroxide- and glass-ionomer-based root canal sealers. Int End J 2008;41:50-3.

Taveira LAA. Estudo do poder flogógeno da placa dental íntegra e tratada com diferentes soluções extratoras [Dissertação de Mestrado]. Bauru: Faculdade de Odontologia de Bauru da USP; 1988.

Torabinejad M, Eby WC, Naidorf IJ. Inflammatory and immunological aspects of the pathogenesis of human periapical lesions. J Endod. 1985;11(11):479-488.

Trujillo Junior, R; Silva FB; Almeida JM; Sousa SMG. Biocompatibility of citric acid in diferent concentrations - edemogenic test. Salusvita; 22(2):17-180, 2003.

Udaka K, Takeuchi Y, Movat HZ. Simple method for quantitation of enhanced vascular permeability. Proc Soc Exp Biol Med 1970;133:1384-7.

Veiga VF Jr, Zunino L, Calixto JB, Patitucci ML, Pinto AC. Phytochemical and antioedematogenic studies of commercial copaiba oils available in Brazil. Phytother Res 2001 Sep;15(6):476-80.

Wilhelm DL. Patologia. Rio de Janeiro: Guanabara Koogan; 1982.

Woods KL, Smith LJ, Graham DY. Intragastric accumulation of Evans blue dye as a method for assesing aspirin-induced acute gastric mucosal injury in humans. Dig Dis Sci 1988;33:769-73. 
ANExOS 


\title{
UNIVERSIDADE DE SÃO PAULO \\ FACULDADE DE ODONTOLO(IAA
}

\author{
PARECER DE APROVAÇÃO \\ PROTOCOLO $n^{\circ}$ 04/06
}

Com base em parecer de relator, o Comitê de Ética em Pesquisa Subcomissão de Bioética de Animais da FOUSP, APROVOU o protocolo de pesquisa "Resposta tecidual imediata frente a cinco cimentos endodônticos", de responsabilidade da pesquisadora Rocio Anahí Zaragoza, sob orientação do Professor Doutor Marcelo dos Santos.

Cabe ao responsável enviar relatórios referentes ao andamento da pesquisa após 06 (seis) meses e 01(um) ano desta data, bem como cópia do trabalho em "cd" ou "disquete" ao finalizá-lo, conforme legislação vigente.

São Paulo, 09 de agosto de 2006

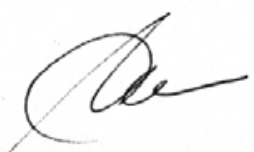

Prof. Dr. Celso Luiz Caldeira

PRESIDENTE DA SUBCOMISSÃo DE BIOÉTICA DE ANIMAIS DA FOUSP 
ANEXO B - Ficha para Controle de Experimento

FICHA PARA CONTROLE DE EXPERIMENTO - TESTE EDEMOGÊNICO

PÓS-GRADUANDA: ROCIO ANAHI ZARAGOZA (ENDODONTIA-FOUSP)

ORIENTADOR: PROF. DR. MARCELO DOS SANTOS

ACOMPANHAMENTO: DOUTORANDO PROF. EDUARDO AKISUE

ANIMAL:

PESO:

DATA:

HORA DA ANESTESIA:

DOSE XILAZINA:

DOSE QUETAMINA:

HORA DA INJEÇÀO DO AZUL DE EVANS:

HORA DA IMPLANTAÇÃO SUBCUTÂNEA DAS SUBSTÂNCIAS:

MATERIAIS E QUADRANTES:

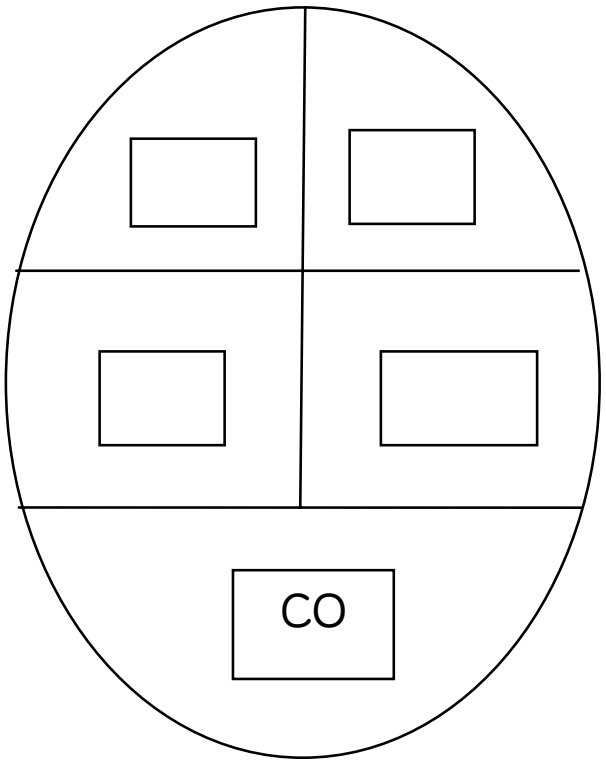

LEGENDA:

AGVP - AcvtiV GP

$\mathrm{AH}-\mathrm{AH}$ Plus

BS - Biosealer

CO - Controle

RS - RealSeal

RK - RoekoSeal

HORA DA REMOÇÃO:

TEMPO EXPERIMENTAL:

ESPECTROFOTOMETRIA

\begin{tabular}{|c|c|}
\hline GRUPO & INDICE DE ABSORBÂNCIA \\
\hline & \\
\hline & \\
\hline & \\
\hline CO & \\
\hline & \\
\hline
\end{tabular}


ANEXO C - Quadros completos com os resultados de todas as amostras expressos em absorbância, suas médias e conversão para $\mu \mathrm{g}$

\begin{tabular}{|l|l|l|l|l|l|}
\hline $\mathbf{6}$ horas & ActiV GP & Biosealer & RealSeal & RoekoSeal & AH Plus \\
\hline $\mathbf{1}$ & 0,912 & 0,462 & 0,904 & 0,123 & 0,876 \\
\hline $\mathbf{2}$ & 0,742 & 0,345 & 0,986 & 0,212 & 1,021 \\
\hline $\mathbf{3}$ & 0,461 & 0,221 & 0,777 & 0,316 & 1,344 \\
\hline $\mathbf{4}$ & 0,723 & 0,464 & 1,676 & 0,196 & 0,802 \\
\hline $\mathbf{5}$ & 0,849 & 0,546 & 0,594 & 0,245 & 0,784 \\
\hline $\mathbf{6}$ & 0,494 & 0,712 & 0,996 & 0,447 & 1,046 \\
\hline $\mathbf{7}$ & 0,701 & 0,335 & 0,343 & 0,176 & 0,843 \\
\hline $\mathbf{8}$ & 0,643 & 0,257 & 0,646 & 0,192 & 1,613 \\
\hline $\mathbf{9}$ & 0,922 & 0,472 & 0,723 & 0,353 & 0,744 \\
\hline $\mathbf{1 0}$ & 0,646 & 0,121 & 0,874 & 0,446 & 0,941 \\
\hline $\mathbf{1 1}$ & 0,530 & 0,108 & 0,912 & 0,109 & 0,773 \\
\hline $\mathbf{1 2}$ & 0,433 & 0,343 & 0,876 & 0,131 & 1,024 \\
\hline $\mathbf{1 3}$ & 1,080 & 0,212 & 1,433 & 0,195 & 0,893 \\
\hline $\mathbf{1 4}$ & 0,951 & 0,843 & 1,574 & 0,243 & 0,676 \\
\hline $\mathbf{1 5}$ & 0,346 & 0,331 & 0,700 & 0,212 & 0,714 \\
\hline $\mathbf{1 6}$ & 0,967 & 0,379 & 0,715 & 0,333 & 0,847 \\
\hline $\mathbf{1 7}$ & 0,435 & 0,495 & 1,428 & 0,184 & 0,694 \\
\hline $\mathbf{1 8}$ & 1,070 & 0,681 & 0,912 & 0,546 & 1,042 \\
\hline $\mathbf{1 9}$ & 0,941 & 0,687 & 0,974 & 0,551 & 0,983 \\
\hline $\mathbf{2 0}$ & 0,652 & 0,302 & 0,772 & 0,198 & 0,664 \\
\hline Totais & $\mathbf{1 4 , 4 9 8}$ & $\mathbf{8 , 3 1 6}$ & $\mathbf{1 8 , 8 1 5}$ & $\mathbf{5 , 4 0 8}$ & $\mathbf{1 8 , 3 2 4}$ \\
\hline Médias & $\mathbf{0 , 7 2 4 9}$ & $\mathbf{0 , 4 1 5 8}$ & $\mathbf{0 , 9 4 0 7 5}$ & $\mathbf{0 , 2 7 0 4}$ & $\mathbf{0 , 9 1 6 2}$ \\
\hline $\mathbf{M g}$ & $\mathbf{0 , 6 1 0 2}$ & $\mathbf{0 , 3 5 0 0}$ & $\mathbf{0 , 7 9 1 9}$ & $\mathbf{0 , 2 2 7 6}$ & $\mathbf{0 , 7 7 1 2}$ \\
\hline
\end{tabular}

\begin{tabular}{|c|r|r|r|r|r|}
\hline $\mathbf{1 2}$ horas & \multicolumn{1}{|l|}{ ActiV GP } & \multicolumn{1}{l|}{ Biosealer } & \multicolumn{1}{l|}{ RealSeal } & \multicolumn{1}{l|}{ RoekoSeal } & \multicolumn{1}{l|}{ AH Plus } \\
\hline $\mathbf{1}$ & 0,876 & 0,202 & 1,443 & 0,098 & 0,941 \\
\hline $\mathbf{2}$ & 0,542 & 0,318 & 0,782 & 0,121 & 0,877 \\
\hline $\mathbf{3}$ & 0,974 & 0,577 & 0,944 & 0,334 & 0,646 \\
\hline $\mathbf{4}$ & 0,813 & 0,347 & 1,232 & 0,184 & 0,471 \\
\hline $\mathbf{5}$ & 0,684 & 0,445 & 0,645 & 0,212 & 0,846 \\
\hline $\mathbf{6}$ & 0,678 & 0,119 & 0,622 & 0,522 & 0,774 \\
\hline $\mathbf{7}$ & 0,551 & 0,728 & 0,482 & 0,194 & 0,514 \\
\hline $\mathbf{8}$ & 0,882 & 0,343 & 0,551 & 0,273 & 0,324 \\
\hline $\mathbf{9}$ & 0,496 & 0,524 & 0,633 & 0,121 & 0,722 \\
\hline $\mathbf{1 0}$ & 0,551 & 0,710 & 0,346 & 0,246 & 0,546 \\
\hline $\mathbf{1 1}$ & 0,727 & 0,461 & 0,584 & 0,143 & 1,482 \\
\hline $\mathbf{1 2}$ & 0,852 & 0,329 & 1,744 & 0,242 & 0,623 \\
\hline $\mathbf{1 3}$ & 0,944 & 0,312 & 0,523 & 0,441 & 0,885 \\
\hline $\mathbf{1 4}$ & 0,572 & 0,418 & 0,474 & 0,727 & 0,721 \\
\hline $\mathbf{1 5}$ & 0,482 & 0,577 & 0,392 & 0,262 & 0,946 \\
\hline $\mathbf{1 6}$ & 1,389 & 0,288 & 0,874 & 0,164 & 0,781 \\
\hline $\mathbf{1 7}$ & 0,974 & 0,214 & 0,888 & 0,253 & 0,293 \\
\hline $\mathbf{1 8}$ & 0,474 & 0,392 & 0,567 & 0,742 & 0,629 \\
\hline $\mathbf{1 9}$ & 0,816 & 0,172 & 0,874 & 0,182 & 0,781 \\
\hline $\mathbf{2 0}$ & 0,723 & 0,545 & 0,731 & 0,246 & 0,929 \\
\hline Totais & $\mathbf{1 5}$ & $\mathbf{8 , 0 2 1}$ & $\mathbf{1 5 , 3 3 1}$ & $\mathbf{5 , 7 0 7}$ & $\mathbf{1 4 , 7 3 1}$ \\
\hline Médias & $\mathbf{0 , 7 5}$ & $\mathbf{0 , 4 0 1}$ & $\mathbf{0 , 7 6 6}$ & $\mathbf{0 , 2 8 5}$ & $\mathbf{0 , 7 3 7}$ \\
\hline $\boldsymbol{\mu g}$ & $\mathbf{0 , 6 3 1 3}$ & $\mathbf{0 , 3 3 7 5}$ & $\mathbf{0 , 6 4 4 8}$ & $\mathbf{0 , 2 3 9 9}$ & $\mathbf{0 , 6 2 0 4}$ \\
\hline
\end{tabular}




\begin{tabular}{|l|l|l|l|l|l|}
\hline $\mathbf{2 4}$ horas & ActiV GP & Biosealer & RealSeal & RoekoSeal & AH Plus \\
\hline $\mathbf{1}$ & 0,424 & 0,102 & 0,464 & 0,202 & 0,723 \\
\hline $\mathbf{2}$ & 0,553 & 0,094 & 0,872 & 0,218 & 0,646 \\
\hline $\mathbf{3}$ & 0,494 & 0,316 & 0,943 & 0,151 & 0,341 \\
\hline $\mathbf{4}$ & 0,676 & 0,216 & 0,629 & 0,083 & 0,523 \\
\hline $\mathbf{5}$ & 0,392 & 0,194 & 0,489 & 0,082 & 0,646 \\
\hline $\mathbf{6}$ & 0,421 & 0,123 & 0,747 & 0,172 & 0,472 \\
\hline $\mathbf{7}$ & 0,584 & 0,301 & 0,843 & 0,309 & 0,554 \\
\hline $\mathbf{8}$ & 0,722 & 0,182 & 0,423 & 0,115 & 0,723 \\
\hline $\mathbf{9}$ & 0,646 & 0,424 & 0,415 & 0,218 & 0,892 \\
\hline $\mathbf{1 0}$ & 0,555 & 0,163 & 0,543 & 0,118 & 0,815 \\
\hline $\mathbf{1 1}$ & 0,479 & 0,343 & 0,217 & 0,072 & 0,626 \\
\hline $\mathbf{1 2}$ & 0,623 & 0,252 & 0,842 & 0,131 & 0,517 \\
\hline $\mathbf{1 3}$ & 0,482 & 0,091 & 0,628 & 0,458 & 0,844 \\
\hline $\mathbf{1 4}$ & 0,441 & 0,144 & 0,781 & 0,145 & 0,543 \\
\hline $\mathbf{1 5}$ & 0,242 & 0,232 & 0,899 & 0,214 & 0,203 \\
\hline $\mathbf{1 6}$ & 0,616 & 0,157 & 0,464 & 0,195 & 0,482 \\
\hline $\mathbf{1 7}$ & 0,723 & 0,234 & 0,577 & 0,234 & 0,333 \\
\hline $\mathbf{1 8}$ & 0,431 & 0,094 & 0,810 & 0,339 & 0,596 \\
\hline $\mathbf{1 9}$ & 0,524 & 0,216 & 0,502 & 0,144 & 0,810 \\
\hline $\mathbf{2 0}$ & 0,697 & 0,172 & 0,692 & 0,227 & 0,772 \\
\hline Totais & $\mathbf{1 0 , 7 2 5}$ & $\mathbf{4 , 0 5}$ & $\mathbf{1 2 , 7 8}$ & $\mathbf{3 , 8 2 7}$ & $\mathbf{1 2 , 0 6 1}$ \\
\hline Médias & $\mathbf{0 , 5 3 6}$ & $\mathbf{0 , 2 0 3}$ & $\mathbf{0 , 6 3 9}$ & $\mathbf{0 , 1 9 1}$ & $\mathbf{0 , 6 0 3}$ \\
\hline $\mathbf{H g}$ & $\mathbf{0 , 4 5 1 2}$ & $\mathbf{0 , 1 7 0 9}$ & $\mathbf{0 , 5 3 7 9}$ & $\mathbf{0 , 1 6 0 8}$ & $\mathbf{0 , 5 0 7 6}$ \\
\hline
\end{tabular}

